
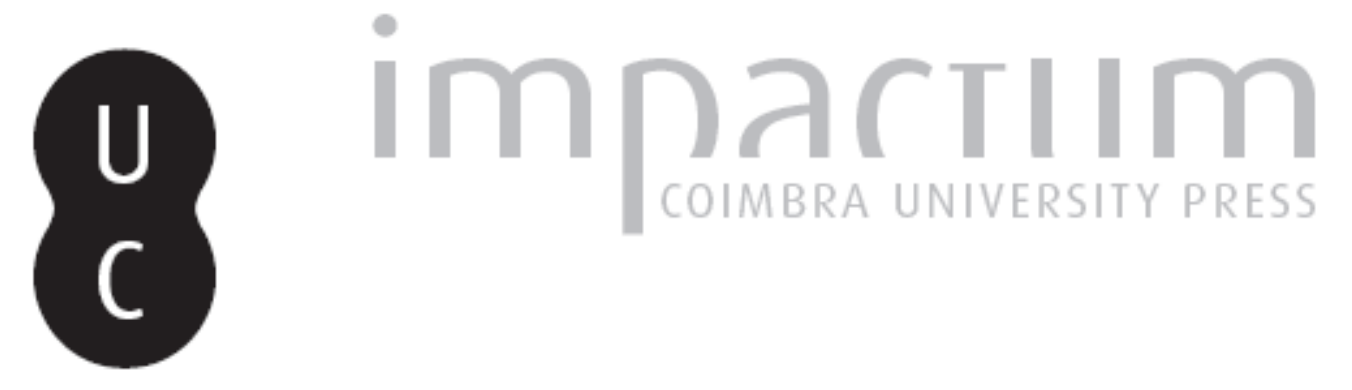

\title{
O contributo de Marx para o Marxismo
}

\author{
Autor(es): Ribeiro, Sérgio
}

Publicado por: Faculdade de Direito da Universidade de Coimbra

URL persistente:

URI:http://hdl.handle.net/10316.2/30702

DOI:

DOI:http://dx.doi.org/10.14195/0870-4260_55_2

Accessed : $\quad$ 26-Apr-2023 03:04:47

A navegação consulta e descarregamento dos títulos inseridos nas Bibliotecas Digitais UC Digitalis, UC Pombalina e UC Impactum, pressupõem a aceitação plena e sem reservas dos Termos e Condições de Uso destas Bibliotecas Digitais, disponíveis em https://digitalis.uc.pt/pt-pt/termos.

Conforme exposto nos referidos Termos e Condições de Uso, o descarregamento de títulos de acesso restrito requer uma licença válida de autorização devendo o utilizador aceder ao(s) documento(s) a partir de um endereço de IP da instituição detentora da supramencionada licença.

Ao utilizador é apenas permitido o descarregamento para uso pessoal, pelo que o emprego do(s) título(s) descarregado(s) para outro fim, designadamente comercial, carece de autorização do respetivo autor ou editor da obra.

Na medida em que todas as obras da UC Digitalis se encontram protegidas pelo Código do Direito de Autor e Direitos Conexos e demais legislação aplicável, toda a cópia, parcial ou total, deste documento, nos casos em que é legalmente admitida, deverá conter ou fazer-se acompanhar por este aviso.

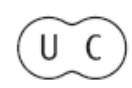


VOLUME LV

$\begin{array}{llll}2 & 0 & 1 & 2\end{array}$

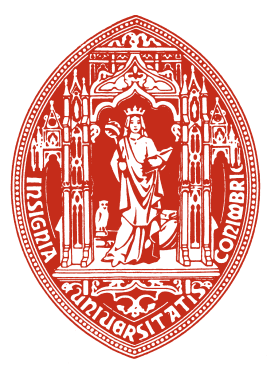




\section{O CONTRIBUTO DE MARX PARA O MARXISMO}

1. - Em carta a Engels de 27 de Abril de 1867, Marx escreveu que "o que há de melhor no meu livro [O Capital] e aí repousa toda a compreensão" foi ter encontrado, no trabalho, o seu caráter duplo, o dualismo que se exprime em valor de uso e em valor de troca, e ter tratado a mais-valia independentemente das formas particulares (lucro, rendas, juros, despesas) que viesse a tomar nas metamorfoses do capital que, como relação social, nelas se materializa.

Marx acrescenta que "o estudo dessas formas particulares da mais-valia, quando confundido com o estudo da forma geral à maneira dos economistas clássicos, dá uma misturada informe", uma verdadeira salada, como também é possível traduzir... E confessa "ter suado as estopinhas para chegar às próprias coisas, quer dizer, à sua conexão”.

Chegar às próprias coisas, às suas conexões: eis uma formulação que pode bem servir para matriz do marxismo! Desde Marx, e do seu contributo para o marxismo. De que, evidentemente, se não pode prescindir.

Este é um objetivo de estudo. Ambicioso. Imprescindível. Que deve estar sempre presente. Que continua. Que nunca se resolve porque o marxismo não foi conversa acabada em Marx. E há que o continuar, para que ele permaneça como guia de ação. No confronto permanente com a realidade. No estudo. A partir de uma base teórica. Para a qual o contributo de 
Marx foi (e continua a ser!) origem e avaliação. Não como dogma. Sempre como ponto de partida.

2. - Ora é precisamente a salada de que Marx fala nessa carta que é mexida pelos economistas, por muitos dos que por aí (e não só por aqui...) pululam, passando, em rotatividade e promiscuidade, por ministérios vários, por diversos cargos políticos e por postos de comando de empresas e grupos empresariais, sempre atarefados por todo o lado, e em que o que menos passou a contar foi a dita Economia, de que sempre se foi mantendo a designação, impropriamente, como impropriamente os ditos "economistas" se auto-designam, e são chamados (sem aspas!). E alguns até sem terem diplomas e curricula, mas tão-só por se terem especializado em... finanças. Em finanças públicas, nas dos patrões e nas suas. De que são muito ciosos.

Mais grave é que a confusão entre a forma geral e definidora de mais-valia, no sentido marxista, e as formas particulares que ela possa vir a tomar, resulta de se ignorar (ou querer ignorar) que a mais-valia nasce da criação de valor, que apenas existe, sempre e só, por via do trabalho. $\mathrm{Na}$ raiz de todas as confusões está este facto, que como facto tomam os que se querem marxistas, facto que se esquece ou que nunca se lembra. E que Marx veio acrescer, como seu contributo, a séculos de reflexão séria sobre a produção de valores de uso, sobre a Economia.

É por aí que se chega a todos os outros saberes da Economia, uma vez que, sem essa base, sem a produção do que satisfaça as necessidades do animal humano, se procuram as soluções económicas na distribuição, na repartição de rendimentos, nas formas de financiamento, na maior ou menor intervenção do estado, em tudo que 'se cria' especulativo e fictício, sem base material, como se todas estas formas existissem independentes ou autónomas das relações sociais na produção. E não fossem por estas condicionadas. 
3. - No entanto, essa confusão (ou salada) também se encontra entre muitos dos que se assumem como marxistas, por insuficiente aprofundamento, por abreviado ou por transviado, de alguns dos conceitos essenciais do materialismo histórico e do materialismo dialético, ou por facilitação na formação ideológica, por imitação e competição ínvia e enviesada.

Esta situação está, evidentemente, ancorada num ambiente geral envolvente, no baixo nível cultural da população de que somos parte. O que é muito agravado pela obstaculização constante de todo o estudo e debate dos contributos de Marx, de companheiros e de continuadores, para a compreensão do processo histórico e conceção materialista-dialética da vida e do mundo. Com deturpação constante dos conceitos, em particular daqueles que nos são essenciais.

A luta de classes tem, também, expressão - e violenta - na massificação da mensagem e da 'informação', sem escrúpulos de fronteira entre a verdade e a mentira, com arbitrariedade e contrafação concetual, com enraizamento de demagogia formatada e formatadora. $E$ as orelhas não podem ficar moucas a tantas palavras ocas e perversas.

4. - Vivemos num momento histórico (com duração de anos) em que o funcionamento da economia capitalista serve para testar as interpretações teórico-ideológicas e em que, também, até pela grande importância do aparelho de informação apropriado pelo capital financeiro, a vertente ideológica da luta de classes instala e instila um pensamento único.

Assim se conformata, por via de uma falsa desideologização e de um pragmatismo de substituição e com todo o aparato, pompa e circunstância, e 'ares' e aparências de cientificidade, uma eufemisticamente chamada "economia de mercado", cujo funcionamento é, no entanto, afrontado e brutalmente contrariado pela realidade, com profundas consequências sociais. Justifica-se, por isso, neste terreno, uma atenção redobrada, 
no plano da investigação teórica e no plano da clarificação ideológica. A organização da sociedade, no predomínio das relações sociais de produção que definem o capitalismo enquanto modo de produção e formação social, adapta a superstrutura aos interesses de classe e à relação de forças, e mantém, quanto possível, uma configuração de democracia burguesa, na sua vertente exclusivamente representativa, e em que a democraticidade apenas se avalia (e avaliza) pelo direito ao voto periódico e desinformado...

E se - e quando! - o voto, em certas condições locais, pende, ou ameaça pender, para pôr em causa essas relações sociais, outras intervenções se engendram, perante nada recuando o poder do capital-dinheiro, segundo e seguindo os 'bons' exemplos 'europeus', em que as votações se sucedem até se conseguir o resultado desejado pelos aparelhos e pelos interesses dominantes.

Pelo que, e para o que, os centros produtores da informação (informação de classe) funcionam a todo o vapor. Ideologizando, sobretudo por injeção contínua de preconceitos e pela divulgação massiva de falsos conceitos, sem recuo perante as mentiras e as 'montagens' falsificadoras de acontecimentos, ou criadoras de não-acontecidos ou de 'cenários'.

5. - É desigual a luta, a luta de classes. Porque as classes nascem das distinções e desigualdades entre os seres humanos. Nascem, entre outras formas, ou de outras maneiras de o traduzir em palavras,

i) de uns seres humanos se apropriarem de outros seres humanos, para destes fazerem instrumentos seus, ou

ii) de uns seres humanos se apropriarem da terra, para que nela se produza o que venha a ser propriedade de aqueles que dela se apropriaram, ou

iii) de, por se terem separado os produtores dos seus meios de produção, terem sido estes apropriados por alguns seres 
humanos, que tomam como seu o que gerações criaram e transformaram, para que, depois, possam tentar tratar a força de trabalho dos desapossados dos seus instrumentos de trabalho como fator de produção, como mercadoria igual a todos os outros fatores de produção.

No entanto, a força de trabalho é mercadoria que nunca poderá ser igual às outras mercadorias, porque é a única que cria valor, e porque representa um conjunto de faculdades físicas e intelectuais (que, no fundo, também são físicas) do ser humano. São essas faculdades que os seres humanos materializam pelo trabalho, que é também atividade racional, pois o que as mãos (simbolizando a energia-força de trabalho) criam como valor é, antes, construído (como ideia...) na cabeça do trabalhador.

Pelo que, os seres humanos, como trabalhadores, são, no capitalismo - e neste criada -, uma classe social, tenha ela de si consciência ou não, sendo o uso mercantilizado da sua força de trabalho determinante para a satisfação das suas próprias necessidades, em condições que definem o estádio (histórico) da relação de forças sociais numa luta de classes, de que são parte, como classe explorada.

6. - A tomada de consciência desta relação é determinante.

Também para o funcionamento da economia capitalista. Não só porque do nível de consciência de classe, particularmente do nível de consciência da classe explorada, depende o grau de intensificação da exploração do trabalhador, mas simultaneamente porque esse nível está condicionado pela informação, que é cada vez mais importante na luta de classes. Porque os meios de comunicação e os veículos de informação observam um desenvolvimento acelerado, e por vezes vertiginoso, mas igualmente porque o funcionamento da própria economia capitalista exige que haja, progressivamente, força de trabalho cada vez mais qualificada, isto é, com formação, o que implica 
informação, por mais condicionada que esta seja. E implica contradições, com reflexos incontroláveis no confronto de classes.

Daqui resulta que, de um lado da 'trincheira' (e a terminologia bélica não é despropositada), uma classe se apropria e usa os meios de comunicação como arma privilegiada para a exploração e, também, ao mesmo tempo, para a batalha ideológica, sendo esta uma vertente cada vez mais importante da luta de classes, até pela manipulação para cobertura política democrática do que é uma 'ditadura económica'. E resulta também que, do outro lado da 'trincheira', a "vanguarda" da classe explorada tem consciência da importância dessa batalha e das contradições que lhe estão inerentes, embora não só lhe faltem os meios, como esteja também em desvantagem no que concerne a outras condições para a luta.

O que só releva a necessidade de reforçar essa vertente, a vertente ideológica, em que, em contrapartida, o sentido da História é favorável aos trabalhadores por ser de humanização e socialização, mesmo quando as aparências momentâneas (historicamente) possam parecer negá-lo.

7. - A importância que tem de ser dada à vertente ideológica da luta de classes (a começar, evidentemente, pela assunção de a História ser a história da luta de classes desde que, e enquanto, classes sociais existam) deve, também, ser um exercício de humildade, isto é, a convicção de que o nosso pensamento não é único e não tem de ser, necessariamente, o melhor, o acabado, o definitivo. No permanente fluir da História, a cada momento (histórico) mudam as coisas, e estas alteram o modo e o ritmo do fluir da História. Não quer isto dizer que não haja conceitos básicos, ou que não haja uma metodologia de abordagem, ou uma clara 'leitura' da realidade. Quer dizer que não há modelos, que não há manuais, que não há pensamento único (ou contra-pensamento único). Quer dizer que não há receitas... a que a realidade se tenha de ajustar. 
A ausência de arrogância é intrínseca ao comportamento coerente com o marxismo. Guia para a acção (a $11^{\text {a }}$ Tese sobre Feuerbach é referência obrigatória: "Os filósofos têm apenas interpretado o mundo de maneiras diferentes; a questão, porém, é transformá-lo”), a transformação da realidade nunca pode ser a tentativa de formatar a realidade a um modelo pré-estabelecido.

O Capital não é um livro, no sentido de ter sido escrito para ser assim editado, numa data, a que se teriam seguido edições ao longo de século e meio. O marxismo não tem um antigo e um novo 'testamento'. O Capital nunca poderá ser, para os marxistas, um manual, uma Bíblia. Como os marxistas devem ler a História, não há nenhuma 'receita' para a transformação do mundo. A questão é que há que transformá-lo.

8. - A economia real (o que se possa assim chamar) não se interrompe. Inexoravelmente, gerações de seres humanos procuram viver, ser humano a ser humano, o mais tempo possível, como matéria organizada que cada um é; cooperam no/dividem o trabalho para colher, semear, transformar, pôr a natureza ao serviço da satisfação das necessidades (suas e de outros). Satisfeitas as necessidades básicas, ficam os seres humanos libertos para que outras nasçam (ou sejam feitas nascer como desejos criados). Mas o funcionamento da economia é, sempre, um modo de produção. Em capitalismo, este é um processo de produção (e acumulação) do capital, que se concretiza no interior de um processo de circulação do capital, e se totaliza num processo total da produção capitalista, estando assim 'arrumados' os três livros de O Capital (obra não revista por Marx, e sempre incompleta, repete-se, à exaustão).

Desde logo, por definição, exige-se uma prevenção. A de que o capital é, antes de mais, uma relação social (de produção), o quer dizer que o capitalismo se funda não sobre uma relação entre os seres humanos e as coisas que os rodeiam, ou sobre uma 
relação entre estas, mas sobre uma relação entre seres humanos, dispondo uns da propriedade de meios de produção e dispondo outros, exclusivamente, da sua força de trabalho.

Partindo da concepção materialista e dialética do mundo (a nossa base teórica), resulta a interpretação do funcionamento da economia, tal como Marx o deslindou, no tempo e nas condições em que construiu a sua (e por nós adoptada... mas de forma necessariamente crítica) crítica da economia política.

9. - «A riqueza das sociedades nas quais domina o modo de produção capitalista aparece como um "imenso acumulamento de mercadorias", sendo a mercadoria singular a sua forma elementar. A nossa investigação começa, por isso, com a análise da mercadoria». ${ }^{1}$ Assim começa a obra-mestra do marxismo (obra não acabada, porém, como vale a pena repetir infatigavelmente). E logo se começa por ter "matéria" para muita reflexão. A ligação aos autores da chamada "escola clássica" aparece de imediato na palavra riqueza, se se tiver presente que Adam Smith - que Marx tão exaustivamente estudou (com respeito, humildade e acerado sentido crítico) - a usa como palavra-chave. Ora Adam Smith, como se pode ver atrás, intitulou a sua obra principal Uma Investigação sobre a Natureza e as Causas da Riqueza das Nações, mais conhecida simplesmente por $A$ Riqueza das Nações. O que poderia servir de emenda para quem apenas parece conhecer, ou reconhecer, como seus contributos o "mercado" e a "mão invisível", que se tornou em manápula financeira.

Também daí, da 'leitura' e estudo dos “clássicos”, resultou a escolha, feita por Marx, para começo da obra que "passou a limpo’. Em O Capital - Livro Primeiro, Marx transforma a

${ }^{1}$ Transcrevem-se as primeiras quatro linhas do Tomo I do Livro Primeiro de O Capital, Editorial Avante!, Lisboa, 1990 (Edição dirigida por José Barata-Moura e Francisco Melo). 
investigação crítica da economia política em obra escrita, e começa pela análise da mercadoria, onde se materializa, em coisa, o caráter dual do trabalho. Que também se pode exprimir em valor de uso e em valor de troca, no que é uma unidade dialética.

10. - A produção é a atividade humana que, intencional e conscientemente, adapta a natureza, os seus recursos, com a finalidade de criar produtos que satisfaçam as necessidades dos seres humanos. Há, portanto, três vocábulos que sintetizam a chamada economia (política), e que entroncam na produção: necessidades, recursos, atividade (trabalho).

É pelo trabalho que o ser humano age sobre a natureza e a transforma, colhendo e criando - e criando e colhendo - os recursos com que satisfaz as suas necessidades. Assim se cria a utilidade das coisas, através da produção que as faz ter um valor de uso porque satisfazem necessidades. Mas nada se fica por esta formulação.

O valor de uso das coisas - os seus valores de uso - constitui o conteúdo material da riqueza, qualquer que tenha sido o seu modo de produção, e só se 'realiza' no consumo. Para o que a troca e a distribuição se tornaram indispensáveis.

$\mathrm{O}$ que significa que uma coisa pode ter valor de uso sem constituir valor (de troca), sem ser mercadoria. Esta apenas existe na unidade dialética valor de uso-valor de troca. $\mathrm{O}$ ar, a água, os terrenos virgens na natureza têm utilidade, logo, potencial valor de uso, mas não têm valor porque não incorporam trabalho e não são transferidos, por troca, para eventuais consumidores que não os seus coletores ou produtores. E significa, por outro lado, que nenhuma coisa tem valor se não tiver valor de uso, se não tiver utilidade, e o trabalho nela contido não é útil, pois não cria qualquer valor.

11. - Assim, valor só é conceito económico como unidade dialética valor de uso-valor de troca, e pode ser redutor ou enga- 
nador (ou especulativo) o vocábulo valor como sub-entendido, e apenas, valor de troca. Também o trabalho tem um caráter duplo (e dialético), o que Marx considerou o eixo à volta do qual gira toda a compreensão da Economia Política. De uma forma muito simples, pode dizer-se que o trabalho é, por um lado, dispêndio de força de trabalho, das capacidades humanas durante um dado período de tempo, chamando-se-lhe trabalho abstrato, e é este que forma o valor de troca, que é incorporado nas mercadorias e as torna comparáveis; por outro lado, essa incorporação é feita através do trabalho concreto, particular, diferente segundo as mercadorias que cria, e que, concretamente, produz os valores de uso. Este contributo de Marx será, na verdade e como ele escreveu, "o que há de melhor no meu [dele, Marx] livro (O Capital) e aí repousa toda a compreensão (...)". Poderá dizer-se que escassa será a compreensão do que se passou ao longo dos séculos, e do que é histórico na nossa contemporânea idade, sem um conhecimento mínimo do caráter duplo do trabalho e dos conceitos de valor de uso e de valor de troca e, também, necessariamente, da sua unidade dialética. Sobre essa compreensão se escora a contribuição para a crítica da economia política e a compreensão do funcionamento da economia, da apropriação da mais-valia criada na fase das metamorfoses do capital em que o capital toma a forma de capital produtivo.

12. - O chamado processo de produção do capital - sendo este a relação social (de produção) mas tendo, também, uma expressão material - tem a sua fase nuclear na produção (...P...), e concretiza-se, na sua totalidade, nas fases que a antecedem e continuam, como fases de troca igual, em que o capital-dinheiro se metamorfoseia em capital-mercadoria (capital constante e capital variável), para que, em metamorfose sequente, o capital-mercadoria, acrescido do valor incorporado pelo trabalho, se metamorfoseie, de novo, em capital-dinheiro. Assim surge (ou vai surgindo... para que as palavras ganhem dimensão dinâmica) 
toda a importância do dinheiro, indispensável no processo histórico para que, como mercadoria especial, possa haver troca, circulação de mercadorias, circulação que se considera o "ponto de partida do capital".

A transformação de dinheiro em capital é analisada na $2^{\mathrm{a}} \mathrm{sec}-$ ção do Tomo I do Livro Primeiro de O Capital, e pode ser lida como uma viagem pela História, onde se escalpeliza a passagem do dinheiro, enquanto mercadoria específica que possibilita as trocas $(M-D-M)$, ao dinheiro enquanto expressão concreta do capital, para se transformar em capital-mercadoria e, depois, se vir a retransformar em capital-dinheiro $(D-M-D)$.

Esta 'viagem', que se repete sempre diferente, tem a antiguidade de décadas e séculos e, ao longo dos séculos, as mudanças são permanentes e registam acelerações. Marx é o cronista genial dessa 'viagem', mas, como é necessário sublinhar, desde a sua crónica-crítica da economia política, viveram-se enormes mudanças e algumas acelerações inesperadas. Há, pois, que atualizar as crónicas, porque as 'viagens' se fazem de outras e bem diferentes maneiras, que não de diferente modo ou com diferente objetivo.

O marxismo não é uma construção acabada da crítica do funcionamento da Economia Política, sendo O Capital um manual e Marx o nosso profeta. Repete-se (e repetir-se-á...). O tempo - e as condições - em que Marx escreveu os seus manuscritos era(m) bem diferente(s) do(s) que hoje se vive(m). Mas a compreensão do tempo que hoje se vive, e do futuro para que temos o dever de contribuir, em cada momento (histórico) mostra-se mais carente dos conceitos e das conexões que Marx considerou fulcrais, porque estas conexões, bem como aqueles conceitos, devem ser cada vez mais um guia para a ação transformadora e humanizadora, face à realidade. Realidade que, para se ir transformando, não está, evidentemente, à espera dos nossos esforços para a transformarmos. 
13. - Nesta altura das reflexões a partir do contributo de Marx para o marxismo, chegou o momento de abordar dois pontos.

Um primeiro ponto tem que ver com a grande dificuldade em ultrapassar a valoração ética que decorre (ou pode decorrer), da abordagem corrente (e militante) que algumas palavras têm no léxico comum. Como é o caso de valor e de utilidade. Quem cria o valor? Sendo este, segundo o marxismo, criado na esfera produtiva, e tendo nascido a classe operária no bojo do capitalismo, das suas relações de produção, é a classe operária formada pelos trabalhadores produtivos.

Mas quer isto dizer que os outros trabalhadores não teriam o 'mérito' social de serem úteis, por não criarem valores de uso? Seria assim se o significado concetual destas palavras, profundo e essencial, e as imagens a elas ligadas, resistissem, estática ou estagnadamente, à evolução das forças produtivas, ao que o materialismo histórico traduz enquanto leitura da História.

Continuemos, ainda e por agora, sublinhando o caráter coletivo, solidário, da produção. Desde a comunidade primitiva que existe divisão do e cooperação no trabalho. No decorrer dos séculos, graças ao desenvolvimento incessante das forças produtivas, esse carácter coletivo tornou-se cada vez mais social, sempre mais humano. O conceito de trabalho (e de trabalhador) produtivo não se pode dissociar do conceito de trabalho (e de trabalhador) coletivo. Por outro lado, não representará 'menos-valia' social não participar na criação de valores de uso se se participar em atividades que possibilitam, nas esferas da circulação, a atividade na esfera produtiva. Como também não são menos úteis, no sentido corrente, as atividades que permitem o acesso dos consumidores aos valores de uso que lhes satisfazem as necessidades.

Num segundo ponto, importa sublinhar que esta questão ganhou acuidade com a aceleração que o capitalismo trouxe (e nisto reside o seu caráter progressivo) ao desenvolvimento 
das forças produtivas e ao consequente aumento crescente, na composição (orgânica) do capital produtivo, da parcela do trabalho vivo já incorporado nos meios de produção.

Este facto torna mais grave (por alienadora) a separação do trabalhador, proprietário da força de trabalho, dos seus meios de produção, e, noutro plano, essa separação é inevitável e perde visibilidade, levando a tomada de consciência para níveis mais complexos de elaboração.

Se o cavador sente a enxada como sua e indispensável ao que ele, como trabalhador, produz, já o operador de CAD-CAM, que cria, em máquinas de si afastadas, as peças para o automóvel, tem mais distante consciência, por muito maior que seja a sua (in)formação, de que os meios de produção são do trabalhador coletivo (presente e passado) de que ele próprio é parte integrante, imprescindivel.

14. - A composição orgânica do capital tornou-se num dos pilares do pensamento marxista, e é-o porque, a partir da leitura marxista da História (materialismo histórico), ela reflete a evolução do processo histórico, e porque, tratada como "lei", contribui decisivamente para a compreensão do(s) momento(s) histórico(s) e da sua dinâmica. A crescente parcela do capital constante $(K)$ relativamente ao capital variável $(V)$ no capital na sua forma-expressão de capital produtivo não é, no entanto, uniforme e/ou fácil de detetar e compartimentar. $\mathrm{O}$ que se verifica, nomeadamente, no que respeita à localização, na divisão das fases de metamorfose do capital, do trabalho produtivo e do trabalho não-produtivo, divisão que tem a maior relevância por ser do (e no) trabalho produtivo que nasce a mais-valia, logo a exploração, e, assim, o cerne do funcionamento da Economia Política do capitalismo.

Após a guerra de 1939/1945, e no período que se lhe seguiu, os chamados trinta anos de ouro (impropriamente, porque também foram anos de "chumbo" e de "brasa", e até por 
esta ser designação ainda, e por demais centrada num euro/ /atlantismo), foram décadas de prioridade para o crescimento económico. Por isso mesmo, o tema do trabalho produtivo esteve presente no pensamento económico (no pensamento que queria pensar a economia...), e o relevo dado ao trabalho coletivo e sua intrínseca ligação ao conceito de trabalho produtivo foi contributo da maior importância. ${ }^{2}$

15. - Antes da continuidade desta abordagem e reflexões, deverá salientar-se que as necessidades não podem ser colocadas no exterior do pensamento económico, como se a este exógenas.

Se se parte do chamado 'tripé' em que assenta a economia - necessidades, recursos, trabalho -, é o tempo de trabalho que vai para além do tempo necessário para a satisfação das necessidades do trabalhador produtivo que cria a mais-valia. E esta é, como a vemos, a raiz da exploração e a fonte do lucro que 'tem de existir' no final do processo. $\mathrm{E}$ as necessidades não só não são dados exógenos à economia como são intrinsecamente históricas e sociais. Até mesmo as que se poderiam considerar básicas por responderem, materialmente, à sobrevivência do ser humano como matéria organizada, até essas são históricas. Porque diferentes no tempo e no espaço humanizado (o que não quer dizer mais humano...).

Nas palavras de Marx ${ }^{3}$ :

“As próprias necessidades naturais, como alimentação, vestuário, aquecimento, habitação, etc., são diversas segundo as peculiari-

${ }^{2}$ Justifica-se aqui uma referência a um estudo de Jacques Nagels, Trabalho Colectivo e Trabalho Produtivo na Evolução do Pensamento Marxista, publicado em Lisboa pela Prelo, em 1974.

${ }^{3}$ Cfr. O Capital, $1^{\circ}$, I, 198. 
dades climáticas e outras peculiaridades naturais de um país. Por outro lado, o âmbito das chamadas necessidades imprescindíveis, assim como a maneira da sua satisfação, são eles mesmos um produto histórico e dependem, portanto, em grande parte, do estádio de civilização de um país e, entre outras coisas, dependem também essencialmente das condições em que se formou a classe dos trabalhadores livres e, portanto, de com que hábitos e exigências de vida."

Embora muito mais se pudesse (e se fosse convidado a) escrever sobre a evolução das necessidades humanas e a humanização das necessidades, para esta presente finalidade poderá já ser bastante.

16. - Como mercadoria, por troca-compra feita pelo capital na sua forma de dinheiro, e por troca-venda feita pelo trabalhador (que recebe por esta via o que lhe possibilita satisfazer as suas necessidades), a força de trabalho tem valor. Tem valor de uso, como trabalho concreto, como mercadoria associada a outras mercadorias em que, especificamente, incorpora trabalho, e daí que tenha também valor de troca, enquanto trabalho abstrato, equivalente a faculdades ou capacidades humanas despendidas durante um dado período de tempo (o que exige a satisfação das necessidades do trabalhador produtivo).

No entanto, e por isso mesmo, ao contrário de todas as outras mercadorias, "a determinação do valor da força de trabalho contém, pois, um elemento histórico e moral"4, sem prejuízo (ou para além) do que é a sua unidade dialética, enquanto valor de uso/valor de troca.

Para efeitos de 'cálculo', considera-se um dado qual o volume dos meios de vida que satisfazem as necessidades e correspondem a um determinado nível de vida em um determinado país, num determinado período, em um determinado estádio civilizacional. Embora o valor de uso da força de

${ }^{4}$ Cfr. K. Marx, ob.loc.últ.cit. 
trabalho possa ser o mesmo, na produção concreta de um determinado produto (ou de vários produtos), o valor de troca será diferente, variando segundo o local e o nível de vida dos trabalhadores concretos.

Assim se explicam, à luz do marxismo, e no contexto da exploração que é intrínseca ao capitalismo, as deslocalizações e as estratégias de contenção salarial, responsáveis epidérmicas pelos atrasos de níveis sociais e civilizacionais, pelas desigualdades e assimetrias. Elas refletem, podemos acrescentar cada vez mais, a passagem da consideração do tempo de trabalho, material, para a consideração da sua expressão monetária, que se vai afastando do seu inicial conteúdo material.

17. - Após um desvio apenas aparente, retomemos o fio condutor das "esferas do capital" e de como, no processo de produção do capital, se podem definir as situações de trabalho produtivo e de trabalho não-produtivo.

No livro atrás referido, Jacques Nagels apresenta um esquema que tem como base - o que é de relevar - a representação das "esferas de circulação", em que é feita a chamada “troca igual” - D por $M$ e $M$ ' por $D^{\prime}$-, e a representação da fulcral "esfera produtiva" $-\ldots P \ldots-$ em que se cria a mais-valia, e os seus prolongamentos.

Este esquema mostra que não há coincidência ou justaposição do trabalho produtivo (e de trabalhadores produtivos) com a "esfera produtiva", uma vez que nesta se encontram atividades de trabalho não-produtivo (e de trabalhadores não-produtivos). 
Trabalho Colectivo e Trabalho produtivo

\begin{tabular}{|c|c|c|c|}
\hline$D-M$ & $\begin{array}{c}\text { Trabalho } \\
\text { não } \\
\text { produtivo } \\
\left(T_{n p}\right)\end{array}$ & $\begin{array}{r}\mathbf{T}_{\mathrm{np}}- \\
\begin{array}{c}\text { Serviços } \\
\text { financeiros }\end{array} \\
\text { da empresa produtiva } \\
\text { (contabilidade, } \\
\text { relações c/bancos } \\
\text { e mais intermediários } \\
\text { financeiros...) }\end{array}$ & 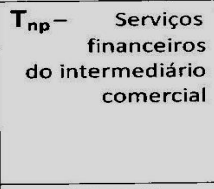 \\
\hline \multirow[t]{2}{*}{... P ... } & & $\begin{array}{r}\text { Tnp } \\
\text { - Actividades } \\
\text { não ligadas à } \\
\text { transformação de } \\
\text { valores de uso }(V . U .) \\
- \text { investigação } \\
- \text { parte dos } \\
\text { quadros dirigentes } \\
\end{array}$ & \multirow[t]{2}{*}{$\begin{array}{r}\text { Custos B } \\
\text { Tp }_{\text {p }} \text { - Transporte } \\
\text { de mercadorias } \\
\text { - "stockagens" } \\
\text { normais } \\
\text { - distribuição }\end{array}$} \\
\hline & & 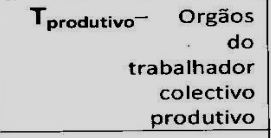 & \\
\hline $\mathbf{M}-\mathbf{D}$ & & $\begin{array}{r}\text { - tempos de vendas } \\
\text { e de compras } \\
- \text { marketing } \\
\text { - publicidade } \\
\text { - "stockagens" } \\
\text { anormais }\end{array}$ & $T_{n p}$ \\
\hline
\end{tabular}

O esquema apenas serve de referência, e foi completado por um outro, do mesmo livro, que se procurou aprofundar, em mais um esquema, para melhor compreender o fenómeno da ligação entre as esferas e os seus prolongamentos e, sobretudo, o facto de a mais-valia, criada em ...P..., alimentar o processo total da produção capitalista. ${ }^{5}$

18. - Como se diz atrás, a divisão dos trabalhadores, segundo o seu trabalho, em produtivos e não-produtivos não tem carga valorativa (num sentido ético). Todos os trabalhadores devem considerar-se como explorados, desde que vendam a sua força de trabalho a quem tenha a finalidade de, com a compra

5 Nos n. os 36 e 37, páginas 29 e 30. 
dela, acumular capital. Mas temos de reconhecer que se torna cada vez mais difícil traçar uma explícita e rigorosa fronteira entre as situações individuais e entre os explorados, sendo perfeitamente justificável dar particular atenção à produção e aos trabalhadores que criam valores de uso.

O estereótipo do operário de fato-macaco sujo de óleo, ferramentas nas mãos ou a manobrar máquinas, deixou de ter sentido (ao menos exclusivo) com o desenvolvimento das forças produtivas. Mas isso não quer dizer que o conceito de produção tenha deixado de estar ligado à criação de valores de uso, à utilidade do trabalho, pela criação material das coisas que são indispensáveis para a satisfação de necessidades humanas.

A complexidade da função produtiva, acompanhada pela cortina de fumo da desinformação sobre a "esfera produtiva", onde $\boldsymbol{K}$ cresce proporcionalmente mais que $\boldsymbol{V}$, fazendo parecer que é o homem que serve a máquina e não o contrário, não pode servir para cimentar a mistificação de que as relações são dos seres humanos com as coisas e não, no seu âmago, relações sociais, relações entre seres humanos... com coisas de permeio.

19. - As coisas de permeio! E uma coisa específica com essa função de servir de meio de troca, de equivalente geral, com o valor de uso de ter valor de troca. O dinheiro! Com a função de "medida" de valor. Como mercadoria universal. O que não quer dizer que a coisa-dinheiro possa substituir o conceito-valor. $\mathrm{Ou}$ que o conceito-valor possa ser substituído pela coisa-dinheiro.

Estas reflexões exigem aprofundamento porque se ocupam das escoras do marxismo. Ao serem tratadas superficialmente, fora da abordagem dialética, são o pasto em que se alimenta o anti-marxismo. Enquanto contributos de Marx, a juntar - como tantos outros - ao que ele próprio definiu como sendo-o, é indispensável a leitura cuidadosa - e nada fácil - do $1^{\circ}$ capítulo da $1^{\mathrm{a}}$ secção do Livro Primeiro, tomo I 
de O Capital, neste caso, sobretudo dos seus pontos 3 e 4 - "A forma-valor ou o valor de troca ( $\mathrm{D}$ - forma dinheiro)" e "O caráter de feitiço da mercadoria (e o seu segredo)".

Ilustremos com duas breves citações ${ }^{6}$ :

"O valor de uso da mercadoria-dinheiro duplica-se. Além do seu valor de uso particular como mercadoria - como, por exemplo, o ouro servir para a obturação de dentes cariados, matéria-prima de artigos de luxo, etc. -, ela adquire um valor de uso formal, que surge das suas funções sociais específicas."

"Mas é precisamente esta forma pronta - a forma-dinheiro - do mundo das mercadorias que encobre coisalmente o carácter social dos trabalhos privados e, assim, as relações sociais dos trabalhadores privados, em vez de o revelar."

Quase como curiosidade, anota-se a presença, mais uma vez, no que é matéria de definição, de uma duplicação, de um caráter dual.

20. - Como é esmiuçado no Livro Segundo, sobre $O$ processo de circulação do capital, a forma-dinheiro passou a ser o início e o fim do processo (começar em $\boldsymbol{D}$ e acabar em $\boldsymbol{D}$ '). Ora essa forma-dinheiro da mercadoria passou, ao longo da História, por várias expressões e ganhou novas funções sociais (ou anti-sociais), desde logo ao deixar de ser a mercadoria específica que está no meio do processo de circulação - $\boldsymbol{M}-\boldsymbol{D}-\boldsymbol{M}$ (coisas trocadas por coisas com a 'ajuda' dessa 'coisa específica' por/com essa sua função). Assim se passou, no modo de produção, à fórmula geral

$$
D-M-(\ldots P \ldots)-M^{\prime}-D^{\prime}
$$

${ }^{6}$ O Capital, ed. cit., 107 e 91, respetivamente. 
No seu “esmiuçamento", Marx sublinha, no entanto, que a análise do processo de circulação se deve justapor com concretizações da circulação iniciadas em outras fases, que não na da metamorfose de capital-dinheiro em capital-mercadoria.

$\mathrm{O}$ que importa salientar é que todo o circuito, tal como Marx o 'agarrou' - em particular nos tomos IV e V do Livro Segundo de O Capital -, é feito em valor (na unidade dialética valor de uso/valor de troca), não obstante a introdução do capital--dinheiro e a consequente epifenomenologia dos preços como expressão desses valores. Em todo o circuito. A abri-lo e a fechá--lo. Para reaberto ser.

Por isso mesmo, em coerência com a atenção dedicada, nestas notas ou reflexões, à produção (...P...), é indispensável sublinhar que nas "esferas de circulação" ( $\boldsymbol{D}-\boldsymbol{M}$ e $\boldsymbol{M}$ '- $\boldsymbol{D}$ ') não há alteração de valor, embora possa haver alterações de preços e injeção de instrumentos fictícios, simbólicos, desmaterializados. E estas alterações (que podem tomar a forma de 'injeções' simbólicas ou fictícias, por isso não-materiais) vão tendo crescente influência nas relações sociais, e na materialidade destas, que invadem e pervertem ou subvertem.

21. - Deixando para outras possíveis reflexões e notas a questão da "transformação dos valores em preços", sendo estes a expressão daqueles, as presentes reflexões centram-se no processo de circulação, todo ele analisado em valor, a partir do contributo que, com a definição do seu caráter dual, veio completar a abordagem de David Ricardo.

Embora no bom caminho, os estudos de Ricardo e de outros "clássicos" estariam 'engulhados', tendo atingido o seu "ponto de maturação". Esse contributo da dualidade do valor veio possibilitar, com um caráter decisivo (em 'leitura' subjetiva e evidentemente discutível, claro...), e com a 'ajuda' da filosofia, sobretudo da dialética hegeliana, a compreensão do processo económico (necessidades-recursos-trabalho) e das suas profundas conexões. 
Depois do estudo do Livro Segundo - tomos IV e V -, haverá sempre que procurar 'arrumar' aquelas centenas de páginas, riquíssimas de contributos (e sobre contributos se está a refletir e a escrever...), em esquemas que ajudem a reter os ensinamentos e em que sejam relevadas as formas do capital (e as suas metamorfoses), enquanto expressões materiais da relação social de produção.

Para isso, vale a pena tentar arrolar e fixar as diferentes formas que o capital pode tomar, ao longo de todo o processo de circulação. Representando este exercício uma necessidade por nós sentida, impõe-se reconhecer o seu elevado grau de subjetividade (ou até de atrevimento) e, por isso mesmo, a eventual falibilidade, quer na escolha das formas, quer na sinalética adotada. Fica aberta a discussão.

22. - Tomemos o diapositivo que segue, com a legenda que o acompanha. Com ele não se pretende - até porque seria estulta tal pretensão - propor aqui uma terminologia e sinalética, não obstante parecer da maior utilidade que alguma se adote (ou que se entenda a utilizada). Trata-se, tão só, de deixar claro aquilo de que estamos a falar. A partir do estudo deste esquema poderão encontrar-se - como contributo de Marx - explicações para a crise (das “crises”).

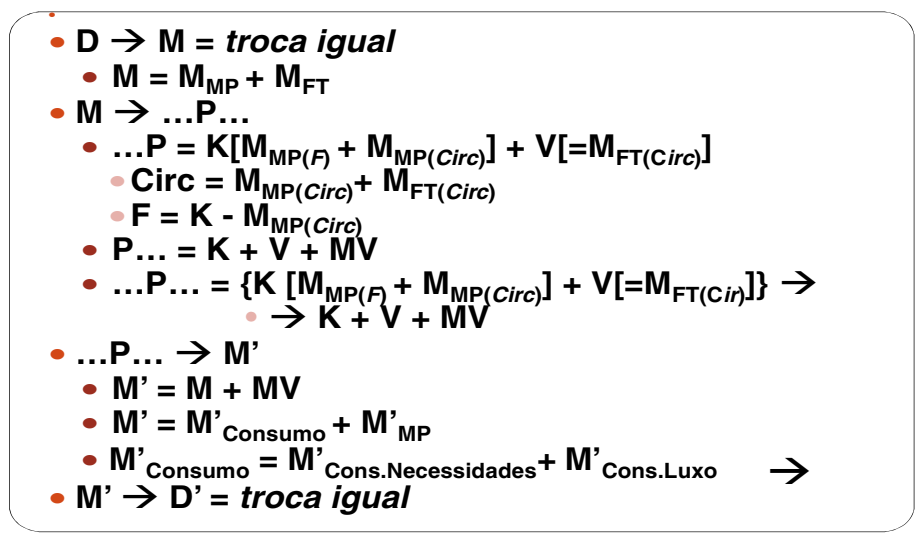




\section{Legenda:}

D $\rightarrow$ capital-dinheiro no início do processo

$\mathbf{M} \rightarrow$ capital-mercadoria

$\mathbf{M}_{\mathrm{MP}} \rightarrow$ mercadoria-meios de produção

$\mathbf{M}_{\mathbf{F T}} \rightarrow$ mercadoria-força de trabalho

$\ldots \mathbf{P} \rightarrow$ fase inicial na esfera produtiva

$\mathbf{K} \rightarrow$ capital-produtivo constante, trabalho cristalizado

$\mathbf{M}_{\mathbf{M P}(F)} \rightarrow$ mercadoria-meios de produção fixos

$\mathbf{M}_{\mathbf{M P}(\text { (irc) }} \rightarrow$ mercadoria-m. de p. circulantes

$\mathbf{V} \rightarrow$ capital-produtivo variável - força de trabalho

\section{$\mathbf{M}_{\mathrm{FT}(\text { Circ })}=\mathbf{V}$}

Circ $\rightarrow$ capital-produtivo circulante

F $\rightarrow$ capital-produtivo fixo

P... $\rightarrow$ fase final da esfera produtiva

$\mathbf{M V} \rightarrow$ tempo de uso de $\mathrm{M}_{\mathrm{FT}}$ para além do tempo necessário para satisfação das necessidades dos produtores, seus proprietários

... P... $\rightarrow$ esfera produtiva total

M' $\rightarrow$ capital-mercadoria com MV incorporada

M' ${ }_{\text {Consumo }} \rightarrow$ capital-mercadoria para satisfação de necessidades

$\mathbf{M}_{\text {Cons.Necessidades }} \rightarrow$ capital-mercadoria para satisfação do que é sentido como necessidades

$\mathbf{M}_{\text {Cons.Luxo }} \rightarrow$ capital-mercadoria para satisfação do não é sentido (ainda?) como necessidades

M' ${ }_{\text {MP }} \rightarrow$ capital-mercadoria sob a forma de meios de produção

D' $\rightarrow$ capital-dinheiro no final do processo

23. - A fórmula geral do processo de circulação do capital pode ter esta representação:

\begin{tabular}{|c|c|c|c|c|c|c|c|c|c|c|}
\hline$D$ & \multicolumn{3}{|c|}{$M$} & \multicolumn{3}{|c|}{$\overline{P . .}$} & \multicolumn{3}{|c|}{$\overline{M^{\prime}}$} & $D$ \\
\hline D & \multicolumn{2}{|c|}{$\mathrm{M}_{\mathrm{MP}}$} & MFt & K & v & MV & \multicolumn{2}{|c|}{$M^{\prime}$ Consumo } & $M_{M P}^{\prime}$ & $D^{\prime}$ \\
\hline & $M_{M P(F)}$ & MMP(Gire) & & & & & $M^{\prime}$ conssec. & $M^{\prime}$ constuxo & & \\
\hline & $\mathbf{F}$ & & Circ & $F$ & & & & & & \\
\hline
\end{tabular}


Nela se destacam as quatro expressões materiais do capital: capital-dinheiro, no início e no final; capital-mercadoria, antes da "esfera produtiva" e depois desta (com trabalho incorporado); capital-produtivo, dentro da "esfera produtiva", na fase de incorporação de trabalho pela força de trabalho usada.

Registam-se também algumas das subdivisões mais significativas nas mercadorias: antes da produção, como meios de produção (sempre instrumentos e/ou objetos de trabalho, por mais sofisticados que sejam), e como força de trabalho; depois da produção, como produtos, (bens de consumo ou novos meios de produção).

Se outro interesse não tivessem, estas representações esquemáticas ajudariam a melhor conhecer o processo de circulação, até chegar ao processo de produção total, após a criação de valor, a obtenção de mais-valia e a sua apropriação (e, no processo, à sua transformação em lucro). Ora o lucro não é, para o capitalista, mais do que a diferença entre $D^{\prime}$ e $\boldsymbol{D}\left(\boldsymbol{D}^{\prime}-\boldsymbol{D}\right)$, entre o capital-dinheiro no início do processo e o capital-dinheiro no final do processo, sendo a taxa de lucro a fração (D'-D) /D.

As distinções entre mais-valia e lucro, entre mais-valia e taxa de mais-valia, entre lucro e taxa de lucro, entre taxa de mais valia e taxa de lucro são essenciais, e muitas das confusões (nem todas inócuas ou ingénuas) nascem da não rigorosa destrinça entre estas categorias conceptuais e as suas resultantes e traduções quantificadas.

24. - Ainda numa outra apresentação gráfica - mais uma para que Marx não poderia ter plenamente contribuído... na ausência de meios, como o Excel, por exemplo - pode relevar-se a importância do trabalho vivo incorporado, origem do valor, na sua unidade dialética. 


\begin{tabular}{|c|c|c|c|c|c|c|c|}
\hline$D$ & \multicolumn{2}{|c|}{$M$} & \multicolumn{3}{|c|}{$\ldots P \ldots$} & \multirow{2}{*}{$\begin{array}{l}M \\
M^{\prime}\end{array}$} & \multirow{2}{*}{$\frac{D}{D^{\prime}}$} \\
\hline$D$ & $M P$ & $F T$ & $K$ & $V$ & $M V$ & & \\
\hline & & & & \multicolumn{2}{|c|}{ trabalho incorporado } & & \\
\hline & & & & tempo & tempo & & \\
\hline & & & & em que & em que & & \\
\hline & & & & se produz & se produz & & \\
\hline & & & & o que & para além & & \\
\hline & & & & satisfaria & do que & & \\
\hline & & & & necessidades & possa & & \\
\hline & & & & dos & satisfazer & & \\
\hline & & & & trabalhadores, & & & \\
\hline & & & & reproduzindo & necessidades & & \\
\hline & & & & & dos & & \\
\hline & & & & força de & que & & \\
\hline & & & & trabalho & produzem & & \\
\hline
\end{tabular}

Importa sublinhar que toda esta análise é feita em termos de valor, e que o dinheiro ainda é, apenas - embora essencial! -, como mercadoria especial, a mera expressão do capital, não refletindo ainda a importância perturbadora que viria a ter na sequência e em consequência da evolução histórica.

Assim pensamos poder contribuir para a compreensão da crise, intrínseca ao capitalismo, sempre larvar, não obstante ocorrerem os seus momentos (históricos) de 'explosão'.

Esses momentos (históricos) de 'explosão’ são as crises periódicas, como acontece neste momento histórico, atual, contemporâneo, de que a desmesurada importância do circuito monetário (e creditício) é fautora visível, com os chamados "excessos" e "desmandos" de alguns, que também servem para a fuga à compreensão das reais e fundas causas das situações que se vivem, por vezes com enorme intensidade e sofrimento. 
25. - A evolução histórica, tudo entre si ligado, tem como motor a relação dos seres humanos com a natureza, o modo como colhem, transformam, põem os recursos, pelo trabalho, ao serviço da satisfação das suas necessidades. O que começaram a fazer com as suas mãos, e passaram a fazer com a ajuda de paus e pedras, de enxadas, de arados, de animais de tração, de fontes de energia que não a dos seus músculos; a percorrer espaços que não sobre as suas pernas, e a organizar-se, dividindo $o$ e cooperando no trabalho. E a não colher e produzir apenas para a satisfação das suas necessidades mas, sempre mais, para trocar pelo que outros coletores e produtores criassem como valores de uso.
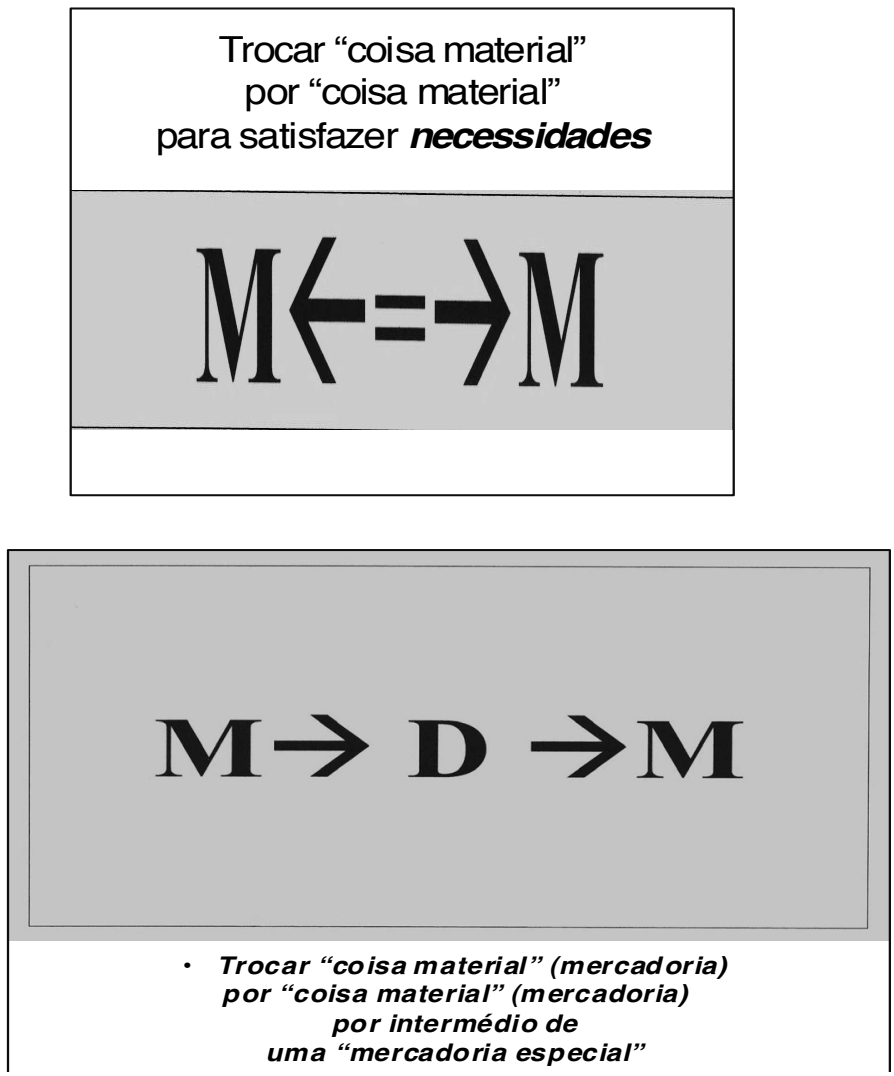
Embora, nesse fluir histórico, a mercadoria especial, intermediária das trocas e equivalente geral, como expressão do "valor das coisas", tenha vindo a ganhar importância crescente na formação (organização) social, em qualquer dos casos, no início e no final das trocas (isto é, no que pretende representar o curso da História) estão coisas materiais, 'produtos' da natureza e do trabalho sobre a natureza e com a natureza, que satisfazem necessidades humanas.

26. - Assim se foram formando dois tipos de circuitos.

Um circuito real, o circuito das coisas que satisfazem as necessidades, primeiro em troca direta, depois usando uma coisa-especial para facilitar as trocas 'coisais'.

Esta mercadoria especial, substituindo-se e melhorando a sua funcionalidade, foi vendo criar-se o seu próprio circuito, derivado e em apoio ao primeiro, apresentando-se como circuito monetário.

\section{Circuitos troca directa e com $\mathrm{D}$ no meio}

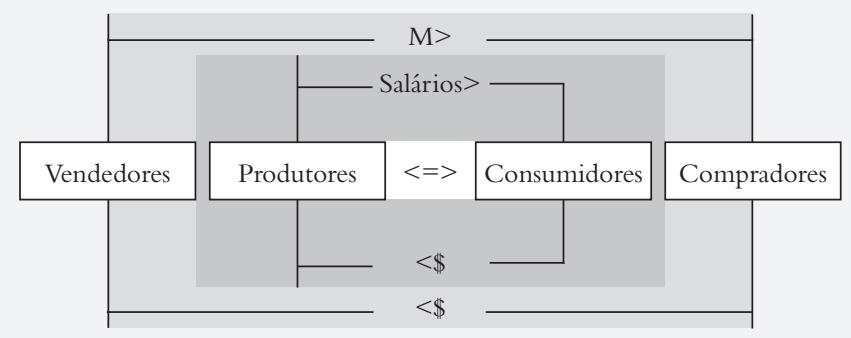


Os dois circuitos, de origens históricas paralelas e quase coincidentes, de sentidos contrários, foram-se modificando, com diferentes tipos de mercadoria especial, nos diferentes tempos e espaços (sal, peles, conchas, metais, sabe-se lá que mais...), ao longo de um processo histórico possibilitado, e acompanhado, e estimulado, pela organização social, decorrente da divisão do/cooperação no trabalho, e pelas formas macroestruturais que se foram criando.

Dos locais de troca, das feiras francas, dos mercados, das cidades, das nações, dos Estados-nações (não como 'invenção' europeia... e exportável), esse longo e diversificado caminho foi tendo tradução na criação da(s) moeda(s), como expressões da "mercadoria especial”, que estava representada em papéis, com sinais não reais mas que corresponderiam a coisas reais existentes, depositadas em locais seguros e de confiança (fidúcia), na posse de representantes também merecedores de confiança das comunidades organizadas. Em alguns casos, espaços e tempos, essa confiança existia porque quem dela desfrutava tinha esse poder por suposta e interposta delegação divina. Em outros, por via de representação sufragada eleitoralmente.

27. - À intromissão do fator confiança deve acrescentar-se a intrusão do fator expectativas, fatores que vieram a ter grande influência no fluir do processo social.

O crédito aparece na economia política como forma de se ter, hoje, acesso a bens materiais, antecipando recursos monetários de que se espera vir a dispor em tempo futuro, como retribuição de atividade produtiva ou outra.

Com a passagem dos séculos, essa ligação umbilical entre as expetativas e a confiança foi-se concretizando através de empréstimos e de juros, sendo estes o 'preço' pago pelo adiantamento de recursos monetários. Por outro lado - e trata-se de questão técnica que não vem a este tema -, a velocidade de circulação da moeda (a quantidade de vezes que a moeda pode 
ser utilizada em operações diferentes) converge com estes fatores para fazer com que o circuito monetário, criado para servir o circuito real, tenha, de certo modo, 'descolado' deste.

Tudo isto pode ser representado em esquema, considerando - para efeitos de visualização - o crédito incluído no circuito monetário, sofrendo este injeções de dinheiro, ainda sem pôr em causa a questão de confiança, isto é, a questão de existir (ou não) uma base material para o dinheiro posto em circulação e/ou para o crédito concedido.

\section{Circuito económico/financeiro com injecção de dinheiro e crédito}

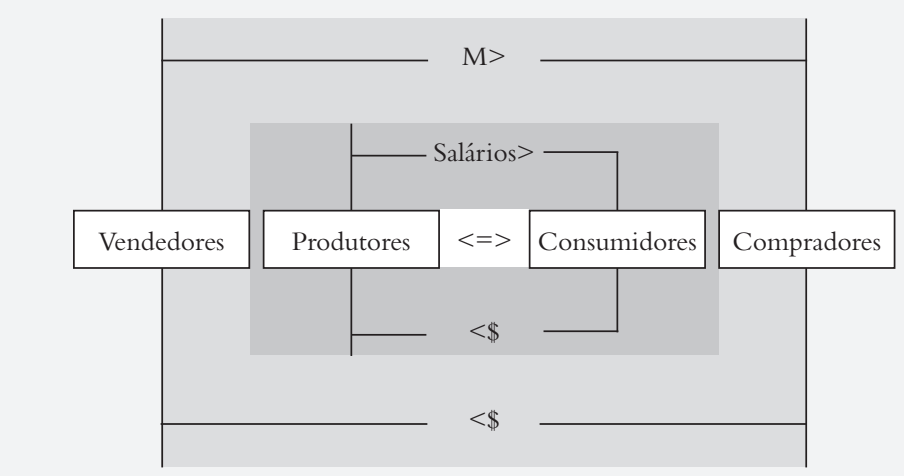

28. - Ao longo dos séculos, tudo se foi enredando. As relações sociais (entre seres humanos) complexificaram-se, a nuvem de coisas que as entretecem foi-se adensando. Com a usura, passou a obter-se dinheiro a partir de dinheiro, por adiantamentos face a expetativas (e ao fito da acumulação).

Em Política Aristóteles defende que "o dinheiro foi criado para ser usado em permuta, mas não para aumentar com usura." Por isso ele entende que esta "forma de ganhar dinheiro é de todas a mais contrária à natureza (...), a mais odiada, e com 
razão", porque a usura "lucra a partir do próprio dinheiro, e não do seu objeto".

Séculos mais tarde, é a vez de Tomás de Aquino (para alguns o patrono dos economistas) perguntar (Summa Theologiae): “ (...) É pecado receber usura por dinheiro emprestado? (...) Eu respondo que receber usura por dinheiro emprestado é injusto, porque isso é vender o que não existe, e isso evidentemente leva à desigualdade, que é contrária à justiça".

No entanto, esses foram os primórdios da economia política, que trouxeram a Humanidade aos começos do capitalismo, em que a passagem da circulação $\boldsymbol{M}-\boldsymbol{D}-\boldsymbol{M}$ à circulação $\boldsymbol{D}-\boldsymbol{M}-\boldsymbol{D}^{\prime}$ tem o maior significado.

E, nesses ainda começos, Marx sublinhava: ${ }^{7}$

“(...) Em primeiro lugar, isto é o curso histórico; [o] dinheiro creditício não desempenha nenhum papel, ou [desempenha um papel] apenas insignificante, na primeira época da produção capitalista. Em segundo lugar, a necessidade deste curso [histórico] é também teoricamente demonstrada pelo facto de que tudo o que de crítico acerca da circulação do dinheiro creditício foi desenvolvido por Tooke e [por outros] os obrigou sempre de novo a regressar à consideração de como a coisa havia de ser exposta na base da circulação meramente metálica".

29. - Deste trecho de Marx importa sublinhar a ideia de que, no processo de circulação, então na "primeira época da produção capitalista”, o "dinheiro creditício não desempenha(va) nenhum papel, ou [um papel] apenas insignificante".

Daí que Marx, ao formular o esquema do processo de circulação, tenha considerado este com base na circulação "meramente metálica", não tendo em conta o que se pode chamar a perturbação necessariamente resultante do afastamento do circuito monetário-creditício da sua base metálica e, por essa via,

\footnotetext{
${ }^{7}$ Livro Segundo, Tomo Quarto de O Capital, ed. cit., 124.
} 
do seu objetivo original e fundador, de apoio e complemento, em sentido inverso, ao circuito real (coisal).

E esta posição metodológica - que consagra o faseamento do modo de produção (e circulação) do capitalismo - é reforçada com a advertência de que outros, que tentaram introduzir no processo de circulação o dinheiro creditício, tiveram de recuar no intento, regressando ao dinheiro meramente metálico.

Aliás, na mesma página,já antes Marx fora claro ao escrever (e Engels, por ele, a editar...) que apenas tomava em consideração o dinheiro como "dinheiro metálico", referindo - e excluindo - o "dinheiro simbólico, meros signos de valor" e o "dinheiro creditício" que, nessa "época da produção capitalista”, não seriam relevantes. Quanto ao dinheiro simbólico, considerava-o "uma especialidade de certos Estados"; do dinheiro creditício dizia que "ainda não está desenvolvido". ${ }^{8}$

30. - O contributo de Marx para o marxismo vai muito para além do tempo em que viveu. Porque Marx procurou, sobretudo, encontrar as dinâmicas da História da Humanidade, as raízes fundas dos comportamentos individuais e coletivos, através de um estudo do vivido até ao seu tempo, com uma base teórica em opções e conceitos histórico-filosóficos, construindo uma interpretação do passado capaz de ajudar a extrapolar para o tempo a ser vivido.

Ler Marx é ter acesso a uma lição de rigor e de modéstia. A frequência com que Marx escreve coeteris paribus (se tudo o mais se mantiver constante) ilustra a preocupação de não fazer

8 " $\mathrm{Na}$ consideração das formas universais do circuito e, em geral, em todo este Livro Segundo, tomamos [o] dinheiro metálico, com exclusão do dinheiro simbólico, meros signos de valor que apenas formam uma especialidade de certos Estados, e [com exclusão] do dinheiro creditício, que ainda não está desenvolvido" (O Capital, últ. loc. cit.). 
afirmações definitivas, pois as conclusões a que se chega num qualquer ramo ou área do conhecimento apenas são conclusões na condição de tudo o mais, exterior à análise feita, se manter constante. $\mathrm{O}$ que pode - e deveria - ser, aqui, escrito com idêntico rigor ao que Marx sempre utilizou, e o é nas intenções, embora em formulação sem dúvida insatisfatória.

A afirmação de Marx de que apenas toma o dinheiro na sua veste de dinheiro metálico, excluindo o que sabe existir mas que, naquele tempo histórico (naquela "primeira época da produção capitalista"), considera pouco relevante, ou insignificante, para a compreensão das conexões essenciais, exige que, mais de um século passado, seja retomada com toda a seriedade. Porque, entretanto, o dinheiro simbólico e o dinheiro creditício foram-se desenvolvendo, e alargaram a sua influência no processo de circulação, aceleradamente depois dos anos 70 do séc. XX.

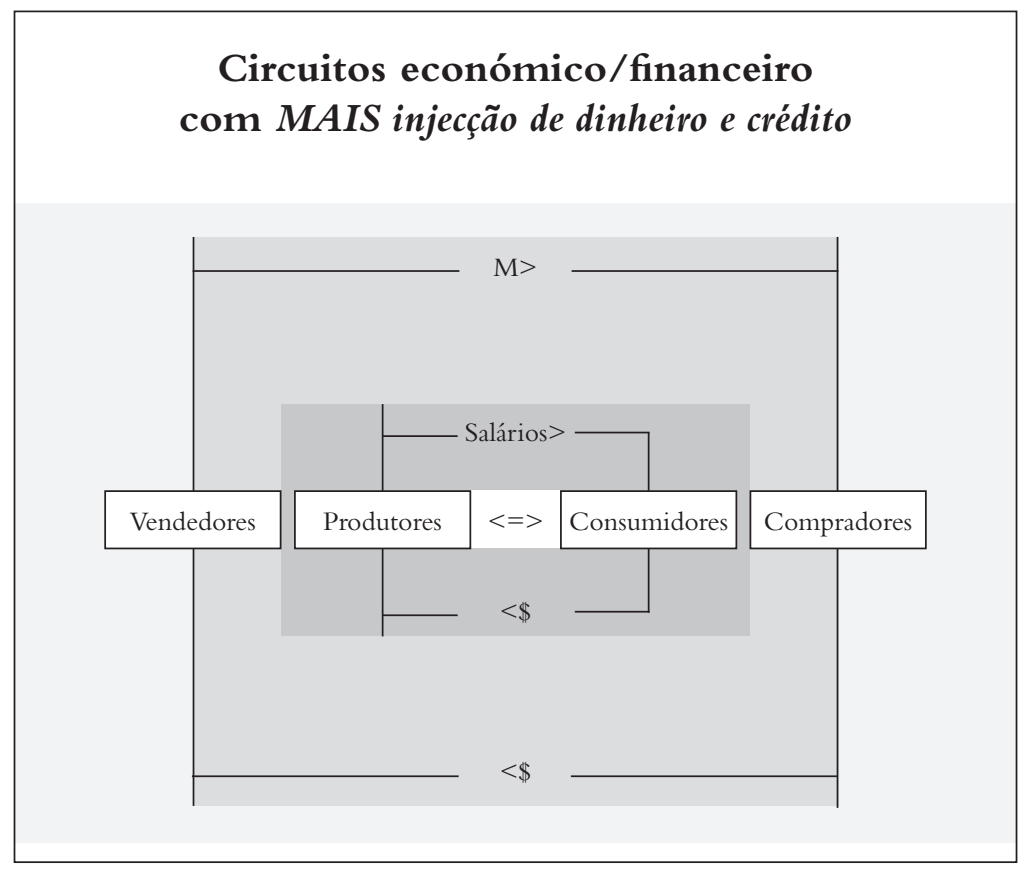


31. - Pode dizer-se que até 15.08.1971 prevaleceu o dinheiro metálico. Embora cada vez mais 'acompanhado' pelo dinheiro simbólico, signo de valor e não expressão deste, e pelo dinheiro creditício, crescendo o crédito e a gestão de expetativas. Após a Grande Depressão (1929-1933), a guerra de 1939-45, com a presença, primeiro resistente, depois alastrando, da realidade do "espetro do comunismo" no contexto internacional, as decisões tomadas em Bretton Woods em 1944 vieram confirmar, no funcionamento capitalista, a prevalência do dinheiro metálico na circulação monetária. O padrão ouro-dólar (consagrado nos Acordos de Bretton Woods) assenta na convertibilidade do dólar em ouro à paridade de 35 dólares por 1 onça troy de ouro, o que significa que os EUA dispunham de 'metal' em quantidades que lhe permitiram fazer da sua moeda a 'moeda do sistema'. Até esse dia! Em que a Administração Nixon rompeu, unilateralmente, os Acordos de Bretton Woods, decisão que tornou fictícia tal relação, confirmou a desmetalização do dinheiro, ou, noutros termos, fez a confissão da fraude que possibilitou o crescimento e o domínio económico dos EUA.

A 'descolagem' do circuito monetário (no qual se inclui o crédito) do circuito da economia real, que se vinha fazendo (pode dizer-se...) paulatinamente - pelo menos em relação ao ritmo que passou a ter - deixou de se poder considerar desequilibrada ou anómala, embora cada vez mais presente e influente, para fazer parte do funcionamento do sistema, do processo de circulação, e ir dele tomando posse.

Mais decisivo é que, com a adoção do monetarismo e a sua transformação em 'arma' no quadro da guerra fria (para além das armas que possibilitava fabricar), passou teoricamente a ter de se considerar o dinheiro simbólico e creditício como o elemento da maior importância no processo de acumulação do capital sob a forma de dinheiro, na passagem de $\boldsymbol{D}$ a $\boldsymbol{D}^{\prime}$ maior que $\boldsymbol{D}$, ainda que $\boldsymbol{D}^{\prime}$ cada vez mais dinheiro não-metá- 
lico, correspondendo à desmaterialização do circuito monetário, à crescente financeirização, no funcionamento do capitalismo, de parte relevante da circulação.

32. - No que pode ilustrar o seu contributo, Marx não quer dizer que não deve considerar-se o "tudo o mais" que ele toma, "naquela análise", como inalterado, e não ignora o que não estima relevante para o que, naquele momento, está a ser analisado nessa crítica. Toda a sua vida é exemplo do contrário, testemunhando sempre a atitude de quem se interessa por tudo que respeite ao ser humano e à natureza de que o humano é parte. Marx sempre privilegiou a abordagem global, e é significativo que, pouco antes de morrer, se tivesse começado a interessar, seriamente, pelo estudo das ciências físico-químicas. O que não representa contradição, antes se trata de questão metodológica. Relativamente ao dinheiro, o facto de, ao analisar o funcionamento do processo de circulação, tomar apenas em consideração o dinheiro metálico significa tão só que, "naquela época do capitalismo", Marx não considerava relevantes nem o dinheiro fictício, simbólico nem o dinheiro creditício.

A prova de que muito lhe interessavam estas expressões do valor está em que, nos manuscritos de que resultou o Livro Terceiro, elas são tratadas com atenção, como o comprova o índice. E o mesmo se passa com o que poderia ser o eventual Livro Quarto, para que há manuscritos bastantes e uma 'arrumação’ que não é da responsabilidade de Engels.

Vale a pena atentar neste trecho do Livro Terceiro de $O$ Capital, colhido em uma edição brasileira: ${ }^{9}$

"se o sistema de crédito é o propulsor principal da superprodução e da especulação excessiva (e) acelera o desenvolvimento material das forças produtivas e a formação do mercado mundial.

9 Trata-se da tradução editada pela Editora Civilização Brasileira, Rio de Janeiro, pag. 510. 
(Ao mesmo tempo,) o crédito acelera as erupções violentas (as crises), levando a um sistema puro e gigantesco de especulação e de jogo."

33. - Esta referência a um sistema gigantesco de especulação $e$ de jogo é (mais) um contributo importante de Marx e tem, na atualidade, toda a pertinência, porque é o capitalismo na sua fase atual.

No entanto, não pode apagar, ou sequer diminuir, as ditas conexões essenciais. E estas estão no contributo de Marx para o marxismo que temos procurado identificar... com estoutro contributo. Fazendo um rápido regresso ao início destas reflexões, lá está o que Marx considerou o que de melhor tem $O$ Capital, "e onde repousa toda a compreensão": os mecanismos que "explicam" a exploração.

Se Marx teria chegado a eles introduzindo o "dinheiro simbólico e creditício" é mera especulação, porque foi usando essa metodologia - também em razão da seriedade intelectual de só avançar por áreas do conhecimento que estudara profundamente - que chegou às "próprias coisas e suas conexões", às relações sociais, aos mecanismos da exploração. ${ }^{10}$

${ }^{10}$ No plano de edição de O Capital pelas Edições Avante!, o Livro Terceiro compor-se-á de três tomos, com sete secções: 1) Transformação da MV em L, e da taxa de MV em taxa de L;2) Transformação de L em L médio; 3) Lei da baixa tendencial da taxa de L; 4) Transformação de M e D em capital de comércio de mercadorias e capital de comércio de dinheiro; 5) Cisão do L em juro (J) e ganho do empresário. O capital que rende J; 6) Transformação do lucro em renda fundiária $\left(R_{f}\right)$; 7) Os rendimentos e as suas fontes.

Os títulos destas sete Secções mostram, com toda a clareza, como Marx procurava contribuir para "o estudo dessas formas particulares da mais-valia (que) quando confundido com o estudo da forma geral à maneira dos economistas clássicos, dá uma misturada informe", uma verdadeira salada como foi dito ser possível bem traduzir, ou seja, tal como já anotámos no início destas reflexões, e como Engels tão autorizadamente interpreta... 
34. - É a partir do trabalho, e do tratamento da mais-valia não confundida nas suas formas particulares, que, nos seus caboucos, o marxismo se constrói, ou melhor, se vai permanentemente construindo. A lei da baixa tendencial da taxa de lucro tem de ser vista como resultante (e peça) dessa construção, enquanto regularidade no funcionamento do capitalismo. A Secção 3 do Livro Terceiro é contributo para evitar a "misturada informe" entre as formas particulares e a forma geral da mais-valia, sendo certo que a expressão do valor em "dinheiro creditício e simbólico" muito estimulou a evolução material das forças produtivas e o mercado mundial (dando ao capitalismo a caraterística de revolucionário, como o faz o Manifesto). A aceleração desta evolução veio a propulsar o gigantismo da especulação e do jogo, como formas de contrariar aquela lei, derivada da evolução da composição orgânica do capital.

$\mathrm{O}$ disparado crescimento de $\boldsymbol{K}$ relativamente a $\boldsymbol{V}$, na composição orgânica do capital, obriga a alterações no funcionamento do sistema com o objetivo de manter $D^{\prime}$ maior (sempre e mais) que $\boldsymbol{D}$, e de contrariar a tendência de menos $\boldsymbol{M} \boldsymbol{V}$.

Há, assim, duas vias de abordagem do capitalismo na época atual. Uma, que decorre do funcionamento intrínseco ao capital como relação social de produção, com a exploração do trabalhador produtivo (cada vez mais coletivo) por apropriação da mais-valia (cada vez mais ser proporcionalmente menor, em virtude do crescente peso de $\boldsymbol{K}$ em relação a $\boldsymbol{V}$ ), e estamos no domínio da exploração. Outra, que se instala por alargamento desmesurado do circuito monetário-creditício, desligado da base material, e estamos no domínio da especulação, orientada para compensar a tendencial queda de $\boldsymbol{M} \boldsymbol{V}$.

Como Marx sublinha (no Livro Terceiro), nos 'fatores' que se opõem à baixa tendencial da taxa de lucro, estes dois domínios cruzam-se na procura de intensificação da exploração, que visa reforçar a componente $\boldsymbol{M} \boldsymbol{V}$ para acrescer $\boldsymbol{L}$, já acrescido, ficticiamente, por via especulativa. 
35. - Assim, o crescente recurso à especulação com o objetivo de acumular capital sob a forma dinheiro (em $D^{\prime}$ ) só confirma a natureza de classe do funcionamento do capitalismo, e vem agudizar a luta de classes. A exploração do trabalhador, através do uso da mercadoria-força de trabalho em tempo de trabalho para além do socialmente necessário, e a apropriação do produto excedente, continua a inalterável matriz do modo de produção e da formação social, e a $\boldsymbol{M V}$ a única fonte material no processo de acumulação.

É este também o entendimento de Jacques Nagels no livro citado, onde representa estas ligações em esquema elucidativo, que se reproduz a seguir. No entanto, a sinalética, ou melhor, as abreviaturas, não são coincidentes com as que temos vindo a utilizar, com $\boldsymbol{S}$ (surplus) como $\boldsymbol{M V}$ (mais-valia), e $\boldsymbol{W}$ (wages) como salário direto ou indireto, querendo $\boldsymbol{p}$ dizer produtivo e $\boldsymbol{u}$ dizer improdutivo.

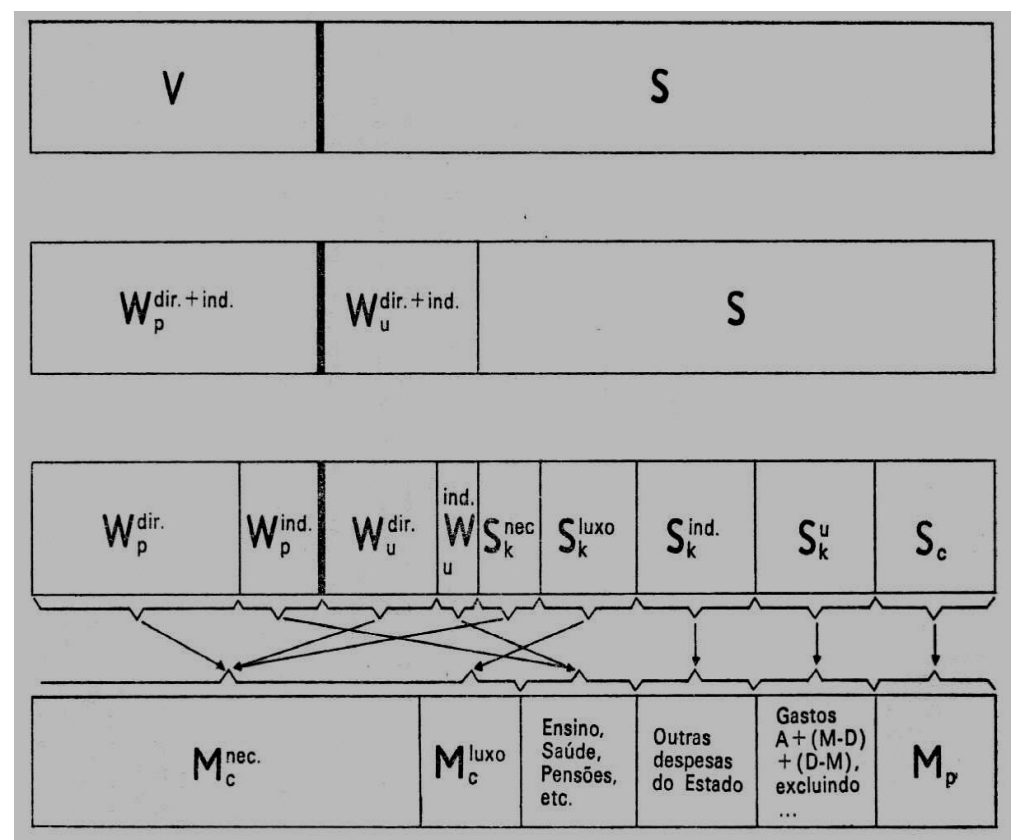


36. - A nossa própria reflexão sobre esta matéria levou-nos a adaptar este esquema, com a intenção de tornar mais clara a conexão essencial. Esta adaptação procura ilustrar como a troca $\boldsymbol{D}$ por $\boldsymbol{M}$, que leva ao uso de $\boldsymbol{V}$ em $\ldots \boldsymbol{P} \ldots$ (onde se acrescenta valor e é apropriado tempo de trabalho não pago - $\boldsymbol{M V}$ ), se transforma em $\boldsymbol{M}^{\prime}$, que é composto de duas partes, que, por sua vez, se repartem de várias formas.

Ou seja, segundo o contributo essencial de Marx, há a troca direta de $\boldsymbol{V}$, por via dos salários diretos dos trabalhadores produtivos, pelo que satisfaça as suas necessidades, e a parte de MV que é usada para que se satisfaçam as necessidades dos trabalhadores não produtivos, ficando o que sobra para satisfazer as necessidades (e os luxos) dos proprietários de $\boldsymbol{K}$, para amortização de $\boldsymbol{K}$ usado na criação de $\boldsymbol{V}+\boldsymbol{M} \boldsymbol{V}$ que leva a $\boldsymbol{M}^{\boldsymbol{\prime}}$, e na acumulação de capital na forma de dinheiro, em $\boldsymbol{D}$ ' $>\boldsymbol{D}$, após metamorfoseado, ou seja, desde que trocado, de maneira direta (e igual) com $\boldsymbol{M}^{\prime}$.

Deixa-se aqui o esquema a que chegámos, apenas para ilustração e registo, e eventual análise e aprofundamento posterior (nosso ou alheio):

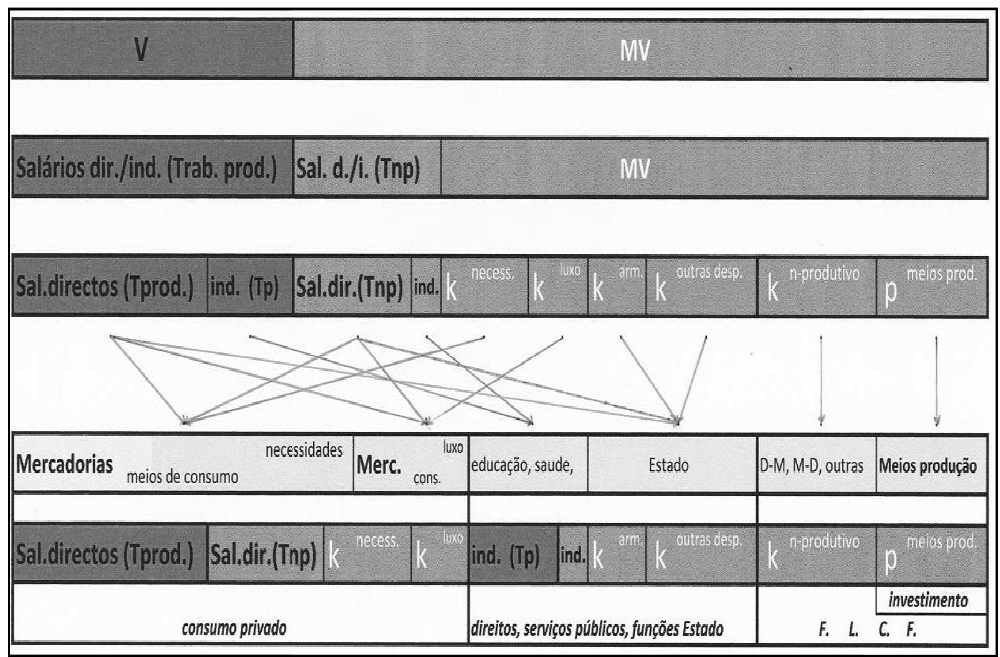


V - capital variável

MV - mais-valia

Sal. - salários/rendimento assalariados

dir., d. - directos

ind., i. - indirectos

Trab. prod., Tprod., Tp. - Trabalhadores produtivos

Tnp. - Trabalhadores não produtivos

$\mathbf{k}$ - mais-valia destinada a meios de consumo

p - mais-valia destinada a meios de produção

Meios de produção, meios prod. - capital constante

arm. - armamento

necess., necessidades - o que como tal é sentido

luxo - o que pode ser dispensado

Mercadorias, Merc. - M' após ... P ...

bens de consumo, cons. - mercadorias sector II

n-produtivo - despesas em D-M e M-D em novos bens de capital constante

não fixo

investimento - compra de novos bens de capital fixo

F.L.C.F. - formação líquida de capital fixo

37. - Retomemos o fio das reflexões (que nunca deixámos, introduzindo apenas aspetos que pareceram oportunos), e sublinhemos, mais uma vez, que Marx escalpeliza o processo de circulação sem nele introduzir o "dinheiro simbólico" e o "dinheiro creditício", porque eles não são suficientemente relevantes nessa etapa do capitalismo, mas também porque toda a análise é feita em valor (tempo) e não nas expressões que ele pode tomar.

Se essas expressões tivessem a importância que atualmente têm na circulação, Marx teria utilizado, por certo, uma forma diferente para desmontar o processo de circulação, mas não deixaria de o fazer em valor. Da evolução da composição orgânica do capital e da decorrente baixa tendencial da taxa de lucro (em termos de valor) resultam crises no capitalismo pelo facto de não se conseguir realizar a troca de $\boldsymbol{M}^{\prime}$ por $\boldsymbol{D}^{\prime}$, de onde uma aparente sobre-produção para trocar por $D^{\prime}$, sendo este o objetivo da classe dominante. 
O decorrente sub-consumo das populações só preocupa a classe dominante quando, ou enquanto, com reflexos na relação de forças sociais.

Vejam-se duas situações (temporais e/ou espaciais) em que se inicia a circulação com a mesma quantidade de capital--dinheiro mas em que a troca $\boldsymbol{D}-\boldsymbol{M}$ reflete as diferenças na composição orgânica de capital (50/50, 70/30), mantendo-se a mesma taxa de mais-valia (100\%), do que resulta uma diminuição da taxa de lucro de 50\% para 30\%.

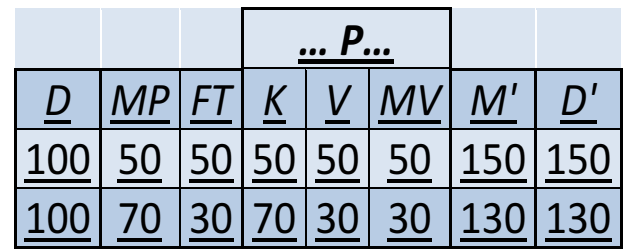

\begin{tabular}{|c|c|c|}
\hline$\frac{\text { Taxa de }}{\text { mais-valia }}$ & $\underline{\text { Lucro }}$ & $\underline{\text { Taxa de }}$ \\
\hline$\underline{D^{\prime}-D}$ & $\frac{\underline{\text { lucro }}}{50 / 50=100 \%}$ \\
\hline$\underline{30 / 30=100 \%}$ & $\underline{50}$ & $\underline{50 / 100=50 \%}$ \\
\hline$\underline{30 / 100=30 \%}$ \\
\hline
\end{tabular}

38. - Sublinha-se que $\boldsymbol{D}$ (tal como $\boldsymbol{D}^{\prime}$ ) é sempre tido como dinheiro metálico, expressão direta de valor. Marx arrola, no Livro Terceiro, os cinco "fatores" que podem contrariar a baixa tendencial da taxa de lucro: i) acréscimo da exploração do trabalho; ii) descida do salário abaixo do seu valor; iii) depreciação de elementos de $\boldsymbol{K}$; iv) sobrepopulação relativa; v) comércio externo. Só indiretamente se poderia encontrar aqui a influência de formas de dinheiro que não a do dinheiro metálico.

A análise tem de continuar a assentar nas conexões essenciais retiradas do contributo de Marx, tal como ele foi "construído", 
nas condições da sua época, com o conhecimento então existente. Hoje, porém, é necessário ter em conta a influente (até decisiva) intromissão de outras formas, e é indispensável, com o agora relevante, estudar a reação "natural" do sistema ao que ele próprio desencadeia no seu funcionamento, na sua procura de contrariar a baixa tendencial do que é o seu objetivo: $D^{\prime}$ maior que $D\left(D^{\prime}-D\right)$, e em relação a $D$.

A reação mais "natural" será a de intensificar a exploração, porque é desta que resulta a mais-valia, "alimento natural" do lucro. Este é, aliás, o significado dos dois primeiros "fatores" enunciados por Marx susceptíveis de contrariar a baixa tendencial da taxa de lucro ( $i$ - acréscimo da exploração do trabalho; $i i$ - descida do salário abaixo do seu valor), dos quais resulta, sem qualquer artificio, o acréscimo da taxa de mais- valia (enquanto maior parcela de tempo de trabalho tomado por não necessário, ainda que seja considerado necessário pelo trabalhador... e, por isso, este se endivide!). Numa situação em que a composição orgânica do capital passa de 50/50 para 70/30, vamos quantificar uma intensificação de exploração, alterando-se (para mais) a taxa de mais-valia para se manter a taxa de lucro:

\begin{tabular}{|c|c|c|c|c|c|c|c|}
\hline & & & \multicolumn{3}{|c|}{$\ldots P \ldots$} & \multirow[b]{2}{*}{$M^{\prime}$} & \multirow[b]{2}{*}{$\underline{D}^{\prime}$} \\
\hline$\underline{D}$ & $M P$ & $\underline{F T}$ & $\underline{K}$ & $\underline{V}$ & $M V$ & & \\
\hline 100 & $\underline{50}$ & $\underline{50}$ & $\underline{50}$ & $\underline{50}$ & $\underline{50}$ & $\underline{150}$ & 150 \\
\hline 100 & 70 & 30 & 70 & $\underline{\underline{30}}$ & 30 & 130 & 130 \\
\hline$\underline{\underline{100}}$ & $\underline{70}$ & $\underline{\underline{30}}$ & $\underline{70}$ & $\underline{\underline{30}}$ & $\underline{50}$ & $\underline{\underline{150}}$ & $\underline{150}$ \\
\hline \multicolumn{2}{|c|}{ Taxa de } & \multicolumn{2}{|c|}{ Lucro } & \multicolumn{3}{|c|}{ Taxade } & \\
\hline \multicolumn{2}{|c|}{ mais-valia } & \multicolumn{2}{|c|}{$\underline{D^{\prime}-D}$} & \multicolumn{3}{|c|}{ lucro } & \\
\hline \multicolumn{2}{|c|}{$50 / 50=100 \%$} & \multicolumn{2}{|c|}{$\underline{\underline{50}}$} & \multicolumn{3}{|c|}{$50 / 100=50 \%$} & \\
\hline \multicolumn{2}{|c|}{$30 / 30=100 \%$} & \multicolumn{2}{|c|}{ 党 } & \multicolumn{3}{|c|}{$30 / 100=30 \%$} & \\
\hline \multicolumn{2}{|c|}{$50 / 30=167 \%$} & \multicolumn{2}{|c|}{50} & \multicolumn{3}{|c|}{$50 / 100=50 \%$} & \\
\hline
\end{tabular}

39. - Nas condições de "dinheiro metálico", ou seja, em valor nas condições da sua expressão através de uma mercadoria 
específica material (a situação que Marx nos legou como base da base teórica), por estas ilustrações se concluiria que, não obstante outros fatores poderem intervir em sentido contrário, a atuação da lei da baixa tendencial da taxa de lucro significa que a taxa de lucro só pode ser reposta - e apenas transitoriamente através da intensificação da exploração do trabalho (mais rigoroso é dizer do trabalhador...), se o estádio de luta de classes a tornar possível.

Sublinhamos transitoriamente, porque a composição orgânica do capital $(K / V)$ tende a crescer - ou a diminuir se encarada como $V / K$, ou como $V / K+V-$, o que pode ser contrariado pela eventual e episódica depreciação de $\boldsymbol{K}$, em termos de valor. Será assim na fase atual do capitalismo, depois de ter passado pela expansão espacial (imperialismo e globalização), e de nela se ter fixado, particularmente depois da queda dos países socialistas europeus.

E há, ainda, a evolução que, sobretudo desde a década de 70 do século passado (depois da referida decisão unilateral da Administração Nixon), acelerou de forma excecional o alargamento do circuito da moeda e do crédito, e a sua 'descolagem' do circuito real, com o "dinheiro simbólico" e o "dinheiro creditício" a tornarem-se predominantes, quando não exclusivos, enquanto a fidúcia (a tão reclamada confiança) se vai perdendo, apesar de ser cada vez mais necessária na atual configuração da democracia burguesa, representativa e demagógica, manipulando a informação... para conseguir o 'voto que convém' e/ou a abstenção 'democraticamente' legitimadores.

Por isso, há que confirmar, teoricamente e em razão da adequação dos conceitos e das conexões, o processo de circulação do capital, com as suas metamorfoses. Mas, ao mesmo tempo, há que introduzir, em devida conta, a consideração da importância da financeirização e da sua desmaterialização em resultado do dinheiro e do crédito fictícios, por lhes faltar suporte material, por circularem por vias etéreas e procurarem desembarcar... off-shore. 
40. - Regressemos à fórmula do processo de circulação de capital:

\begin{tabular}{|c|c|c|c|c|c|c|c|}
\hline$D$ & \multicolumn{2}{|c|}{$\boldsymbol{M}$} & \multicolumn{3}{|c|}{$\ldots P \ldots$} & $M$ & $D$ \\
\hline$D$ & $M P$ & $F T$ & $K$ & V & $M V$ & $M^{\prime}$ & $D^{\prime}$ \\
\hline & & & & \multicolumn{2}{|c|}{ trabalho incorporado } & & \\
\hline & & & & Tempo & Tempo & & \\
\hline & & & & em que & em que & & \\
\hline & & & & se produz & se produz & & \\
\hline & & & & o que & para além & & \\
\hline & & & & satisfaria & do que & & \\
\hline & & & & necessidades & possa & & \\
\hline & & & & dos & satisfazer & & \\
\hline & & & & trabalhadores, & as & & \\
\hline & & & & reproduzindo & necessidades & & \\
\hline & & & & a sua & dos & & \\
\hline & & & & força de & que & & \\
\hline & & & & trabalho & produzem & & \\
\hline
\end{tabular}

Este processo de circulação poderia ser representado de três formas diferentes, consoante a consideração da fase de começo do ciclo. Que pode ser ciclo do capital-dinheiro, tal como representado acima, ou ciclo do capital-produtivo (P-M'-D'... D'-M'-P'), ou ciclo do capital-mercadoria (M'-D'... D'-M'-P'-M').

Estas três representações são muito úteis, ou até necessárias, tal como Marx as analisa no Livro Segundo de O Capital, para o estudo aprofundado da reprodução do capital. Deixamos esta como que ressalva - e 'ponte' para eventuais outras abordagens - com o acrescento de que, na realidade, os três ciclos assim representados ocorrem, ou podem ocorrer, simultaneamente, pelo que a possibilidade de eclosão da crise latente, e inerente ao funcionamento do sistema, se pode apresentar em qualquer deles. 
No entanto, nesta abordagem, continuamos a adotar apenas o ciclo do capital-dinheiro. Fazemo-lo por esta ser a representação geral, que mostra claramente qual a finalidade do processo de produção capitalista - acumular capital-dinheiro a partir da criação e apropriação da mais-valia na fase de produção -, e por ser ela a representação mais simples e familiar. E ainda porque é dessa representação geral que decorrem as outras duas representações, que, no entanto, não podíamos deixar sem referência.

41. - Na atual fase do capitalismo, como temos sublinhado, começou a prevalecer o dinheiro não-metálico, com injeção de dinheiro fictício, por via dos Estados que refletem a relação de forças na luta de classes, e de dinheiro creditício, através do sistema bancário imposto 'dentro' do funcionamento do modo de produção. Assim se agrava a financeirização e a desmaterialização do circuito monetário criado para servir o circuito real, o circuito da circulação das coisas que satisfaçam as necessidades sociais.

Por isso, para além dos "fatores" que Marx identificou como contrários à baixa tendencial da taxa de lucro, é necessário ver como e onde se encontrarão, no processo de circulação, formas de conseguir que, sem alterar o que é intrínseco ao sistema, $\boldsymbol{D}$ ' seja superior a $\boldsymbol{D}$, estando $\boldsymbol{D}$ já, e desde o início, necessariamente influenciado pelo dominante capital-dinheiro fictício e creditício.

Utilizando a fórmula geral do processo de circulação de capital, há dois momentos em que é possível a injeção de capital-dinheiro fictício ou de dinheiro creditício transformado em capital-dinheiro: ou no início do processo, em reforço de $\boldsymbol{D}$, para ser trocado por $\boldsymbol{M}$; ou seja, para que se realize a troca, e assim se anule o que pode tomar a forma de sobreprodução de M' ou de escassez de salários para se aceder a $\boldsymbol{M}^{\prime}$, substituindo-os por dinheiro creditício, ou ainda tomando a forma de dinheiro 
fictício, para que os proprietários dos meios de produção compensem a baixa de $\boldsymbol{M} \boldsymbol{V}$ por efeito da evolução da composição orgânica do capital e possam conseguir que $D^{\prime}$ seja superior a $D$.

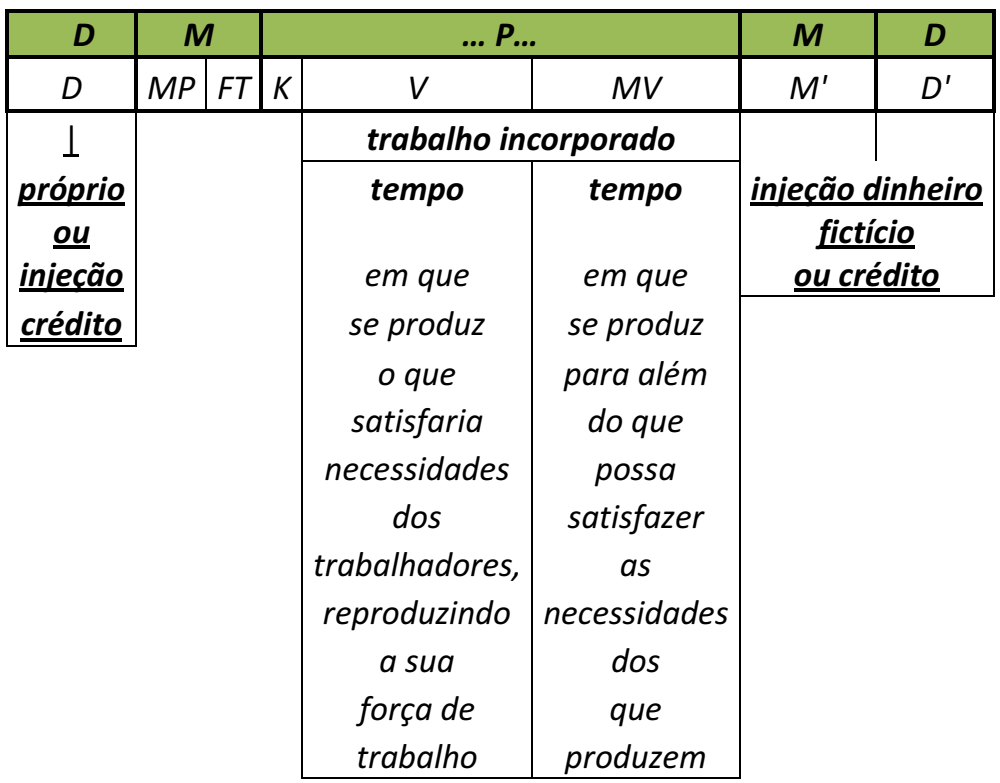

42. - Não ser feita a passagem $M^{\prime}-D^{\prime}$ corresponderá a rotura ou estrangulamento no processo de circulação do capital, o que se procuraria compensar passando a $D$ ” por injeção de mais capital-dinheiro simbólico, ou fictício, ou de mais crédito, em alternativa (ou cumulativamente) com destruição de $\boldsymbol{M}^{\prime}$, assim se passando a $\boldsymbol{M}^{\prime}$, ou seja, menor quantidade de mercadorias em resultado de destruição (guerras como 'saída'). Só nas novas condições se faria a passagem-metamorfose de M' ou de $\boldsymbol{M}^{\prime \prime}$ (menor que $M^{\prime}$, podendo configurar um novo ciclo de capital-mercadoria) a $\boldsymbol{D}^{\prime}$ ou a $\boldsymbol{D}^{\prime}$, ou seja, $\boldsymbol{D}^{\prime}$ mais o injetado capital-dinheiro. 
Estas hipóteses podem concretizar-se cumulativamente ou em alternativa, e representam expedientes de especulação, como forma de acumular capital-dinheiro, sendo parcela cada vez mais relevante de dinheiro ou crédito sem base material num circuito financeiro cada vez mais afastado do circuito real, das coisas que satisfazem necessidades.

Ou seja:

$$
\begin{aligned}
& \text {-4. } M^{\prime} \rightarrow D^{\prime} \\
& \text { (injeção e/ou destruição f.p.) } \\
& \text { - }\{\text { 4. } \rightarrow \text { D" e/ou M', } \\
& \text { ○ 4.1. D', = D'+ crédito e/ou } \mathrm{D}_{\text {simbólico }} \\
& \text { e/ou } \\
& \text { ○ 4.2. M'’<M' (por destruição)\} } \\
& \text { - 5. M' ou M', (<M') } \rightarrow \text { D' ou D'” (>D') } \\
& \text { ○ 5.1. M' } \rightarrow \text { D', } \\
& \text { - 5.2. M' } \rightarrow \text { D' } \\
& \text { ○ 5.3. M' } \rightarrow \text { D' }
\end{aligned}
$$

43. - É desta maneira que a especulação vem em socorro da exploração, que se concretiza pela apropriação de mais-valia e está na génese do modo de produção capitalista, e continua a constituir a sua essência. Sublinhamos, de novo, que a especulação, através da criação e do movimento de capital-dinheiro fictício e creditício, tem importância enormemente crescente. Não 
só em relação ao tempo de Marx mas reltivamente às três últimas décadas, em que acelerou vertiginosamente.

Mas se este 'fator' vem, eventualmente, contrariar a lei da baixa tendencial da taxa de lucro, ele é também, ao fim e ao resto, fictício e efémero, e é apenas uma outra forma de transferir mais-valia criada e apropriada, numa dinâmica de concentração e centralização da "riqueza das nações", "riqueza" que foi criada da única forma que o é, pelo trabalho realizado, pelo valor de uso da força de trabalho. A dramática alternativa é a de destruir "riqueza" para mais a concentrar...

Voltando às tabelas insertas no $\mathrm{n}^{\circ} \mathbf{3 9}$., podemos ilustrar uma evolução em que a relação de forças na luta de classes só permitiu uma intensificação da exploração de $100 \%$ para $133 \%$, e não para $167 \%$, o que a injeção de dinheiro fictício ou crédito veio compensar para se conseguir manter a taxa de lucro de 50\%:

\begin{tabular}{|c|c|c|c|c|c|c|c|}
\hline & & & & $\ldots P \ldots$ & & & \\
\hline$\underline{D}$ & $M P$ & $\underline{F T}$ & $\underline{K}$ & $\underline{V}$ & $M V$ & $M^{\prime}$ & $\underline{D^{\prime}}$ \\
\hline 100 & 50 & 50 & 50 & 50 & 50 & 150 & 150 \\
\hline 100 & 70 & 30 & 70 & 30 & 30 & 130 & 130 \\
\hline 100 & 70 & 30 & $\underline{70}$ & 30 & 40 & 140 & 150 \\
\hline & & & & & & $\begin{array}{l}\text { injeção dinhe } \\
\text { ou créditc }\end{array}$ & $\begin{array}{l}\text { ictício } \\
10\end{array}$ \\
\hline Taxa & mai & -valic & & Lucrc & & Taxa lucro & \\
\hline & $\overline{50 / 5}$ & & & 50 & & $50 / 100$ & \\
\hline & $30 / 3$ & & & 30 & & $30 / 100$ & \\
\hline & $40 / 3$ & & & 50 & & 50/100 & \\
\hline
\end{tabular}

Injeção que pode ser (e é!) desbragadamente aumentada para, ficticiamente, acrescer (e concentrar...) a taxa de lucro. 
44. - Este 'expediente' só é possível nas condições de livre circulação do capital, na sua forma dinheiro. $\mathrm{O}$ que, por outro lado, foi sendo progressivamente facilitado pela própria evolução faz forças produtivas, fruto da incorporação de trabalho vivo $(\boldsymbol{V})$ em trabalho cristalizado $(\boldsymbol{K})$, que criou condições objetivas para essa circulação, enquanto metamorfoses do capital.

Ao insistirmos na influência do capital-dinheiro feito simbólico por ausência de correspondente valor material-metálico, anotamos a referência ao dia em que acabou o sistema ouro-dólar, e outra referência se lhe pode juntar, a da livre circulação de capitais em espaços supranacionais. E anotamos o Acto Único Europeu (1986), que define o mercado interno e as quatro liberdades de circulação, das quais só é total a liberdade de circulação de capitais, nas condições técnico-objetivas entretanto ocorridas.

Foi a livre circulação de capitais que, por via de Maastricht e das Conferências Inter-Governamentais, levou ao euro-instrumento e ao BCE-instituição, que consagram essa liberdade, instrumento e instituição hoje reconhecidamente prematuros por se terem antecipado a condições objetivas talvez sobrevenientes. A sua criação serviu interesses de grupos financeiros, à revelia dessas condições e de soberanias nacionais.

Por si, e pelos mecanismos e pactos que arrastaram, colimados ou em colisão com o domínio dos EUA, foram fautores da "crise" que tantos tanto sofrem.

45. - No entanto, não só a evolução das forças produtivas não pára - com os problemas que levanta por se 'esquecer' que o ser humano faz parte da natureza e que o aproveitamento do meio tem de ser, também, uma tomada de consciência da finitude dos recursos e da necessidade da sua preservação -, como as relações sociais se expandem e modificam. Colónias de ontem são os 'países emergentes' de hoje (com opções de 
recusa do imperialismo), e Estados europeus potenciais beneficiários de uma reequilibradora coesão económica e social do Acto Único, são, hoje, PIGS (com um ou dois I, e mais letras se perfilam), periferias de um centro onde o capital financeiro se concentra. Entretanto, o processo histórico faz o seu curso. Não retilíneo, mas com avanços e recuos, com saltos em frente e quedas desastrosas. Tendencialmente, sempre no sentido da humanização, da socialização.

Estas reflexões procuram compreender, à luz do contributo de Marx, o funcionamento do capitalismo em condições que Marx não considerou. Justifica-se, por isso, juntar algumas observações que justificam mais aprofundada análise.

Sobre a dimensão tempo. Ao lado da invasão da especulação e do "bangsterismo" no circuito económico real, ao serviço da acumulação de capital-dinheiro, operou-se a substituição do padrão-ouro (com a libra a dominar) pelo padrão ouro-dólar, com a sequente internacionalização e depois a imperialização do dólar inconvertível, por dispor da 'impressora' de 'moeda falsa' e comandar a usura que escora a transnacionalização, e a eclosão da... "crise"!

E hoje, depois de ensaios com moedas de $2^{a}$ linha (em relação ao US\$), como o ien e o euro (ou o D.E.S./FMI), a chamada crise financeira veio tornar conflituosa a relação entre as moedas e aparecem surpresas... que seriam de esperar! Que papel virão a desempenhar o yuan, o sucre e outras moedas ou unidades de conta?

46. - Que influência, a nível institucional, poderão vir a ter todos estes arranjos e desarranjos entre Estados (alguns dos quais eram colónias há pouco tempo) inter-dependentes (assimetricamente) do ponto de vista económico e monetário? É de lembrar que, por exemplo, a moeda de ex-colónias francesas era, e em muitos casos continua a ser (com a Guiné-Bissau e a Guiné Equatorial), o franco-CFA (Comunidade Financeira 
de África), mantendo uma ligação umbilical com a inexistente moeda da antiga metrópole. Pode mesmo dizer-se que esse é um problema não resolvido, como não o está em Cabo Verde, ou em Angola, na herança de moedas 'ultramarinas' - e de um BNU, num "império colonial português", ao lado do Banco de Portugal, hoje ilustração de des-soberania - com episódios históricos que merecem estudo. Comprovações de que as moedas não se podem criar desligadas da realidade das economias reais, das 'cousas' no meio das pessoas e não o contrário.

Nos dias de hoje - escrevemos em junho de 2012 -, tudo parece suspenso do euro e do BCE, do que eles são, vierem a ser, ou deixarão de ser, num futuro próximo.

No vício secular de tudo se ver pelo umbigo europeu, a "moeda única" da União Europeia apresentou-se como 'invenção' (!) genial. Não tendo sido, talvez, projetada para a UE mas para uma União Económica e Monetária dos 'países centrais', ela alastrou, penosamente, a 'países periféricos'. Criada sem bases técnicas (como a de zona monetária óptima) ela surgiu por via política ao serviço do capital financeiro. A institucionalização do federalismo serviria para lhe dar cobertura.

Sublinhamos a 'invenção' e os problemas atuais porque eles ilustram a perturbação que o fito da acumulação de capital financeiro veio trazer à economia real. O esforço para contrariar a baixa tendencial da taxa de lucro pela via da especulação é novo vetor suicidário do sistema que só sobrevive com a intensificação da exploração até ao limite do suportável.

47. - Ao empreendermos esta 'viagem' pela financeirização, 'a bordo' do pensamento marxista e com as limitações do 'navegador', pretendíamos, fundamentalmente, dar o nosso contributo para a compreensão de que a dinâmica capitalista não se pode concretizar sem as contradições e os constrangimentos que ela própria cria e agudiza, nem (sobretudo!) fora da relação de forças da luta de classes, em que é determinante 
o papel dos trabalhadores, através das suas organizações, sindicais e políticas.

As contradições e as divisões intra/entre-imperialistas bem podem levantar 'poeira' para tentar impedir que se vejam claros os antagonismos sociais. Procurámos, por isso, pôr em relevo que a centralização e concentração de capitais, mormente na forma dinheiro, resultam da dinâmica capitalista, e que o cerne histórico está na divisão de classes, na exploração do trabalho e na força que as massas tiverem, nas suas lutas a nível local e planetário, para contrariar a intensificação da exploração.

Temos de continuar a observar a problemática das tensões dólar-euro, a manipulação da informação controlada pelo poder financeiro, as alternâncias estratégicas e táticas, num quadro temporal e espacial mais amplo que o século XXI e que as duas margens do Atlântico Norte.

Questões como a de sair ou não do euro não se colocam como sendo de pôr uma cruz num quadradinho. Do mesmo modo que não se colocaram assim as questões de entrar ou não para as "Comunidades", de fazer parte ou não dos 'eleitos' da moeda única.

Com a nossa leitura da História, a nossa base teórica e a nossa ideologia, só poderíamos ser contra a adesão às Comunidades Europeias, naquelas condições, e ser contra a 'entrada no euro', tal como ele foi construído. Com base nestes mesmos pressupostos continuaremos a trabalhar na avaliação das condições em que se coloca a continuidade na/da moeda única.

48. - No processo histórico, tanto os arranjos espaciais entre Estados-nações (não correspondendo este macro-conceito a universal e rígida forma de organização dos povos, com seus percursos próprios de convivências e de culturas seculares), como os instrumentos adequados ao nível de desenvolvimento das relações entre os povos, não são, em si mes- 
mos, 'bons' ou 'maus'. Como não são neutros! Traduzem, nas suas elaborações e concretizações, estádios das relações sociais, relação de força das classes sociais em presença. Quando, no discorrer destas reflexões, escrevemos luta de classes, não estávamos a usar uma frase feita, um slogan, uma expressão adinâmica que pretenda copiar outros modos e tempos que não os tempos e os modos em que a expressão tem real significado. Partindo do princípio de que a base teórica de que partimos é guia para a ação, impõe-se-nos o dever de estudá-la e aperfeiçoá-la, sempre em confronto com a realidade.

A criação do Mercado Comum, as passagens ao mercado interno e à moeda única foram respostas a necessidades objetivas, na relação de forças da luta de classes. Como em todos os ditos "pequenos passos". Abrindo novas frentes, no plano institucional, da luta de classes.

Enquanto se avançava institucionalmente com a integração, continuava a luta de massas. Com conquistas e recuos, com fragilidades e traições das suas vanguardas, que foram avanços nas posições da classe que explora e especula. E que procura, sempre, recuperar conquistas dos trabalhadores e das populações. Pela luta de massas e nos seus reflexos institucionais.

No capitalismo, na vida, as contradições sucedem-se. Mesmo quando parece poder avançar sem constrangimentos, as superações de contradições criam novas contradições.

O momento que se vive, histórico como todos o são (embora alguns sejam mais históricos que outros...), ilustra-o perfeitamente: os problemas criados pelo 'escape' do capital-dinheiro fictício e creditício não se resolvem com a injeção de mais dinheiro falso e de mais crédito. Agudizam-se e criam-se novos.

49. - A imagem do 'balão' que enche e de 'bolhas' especulativas - que as ilustrações atrás poderiam ajudar se, em vez de retângulos para os circuitos, tivéssemos desenhado círculos... - pre(a)nunciam rebentamentos. No entanto, temos 
sempre de ter em conta... a "resistência dos materiais". O capitalismo por si, e por si só, não rebentará. Procurará sempre novas 'saídas', intensificará a exploração e buscará expedientes desmaterializados, artifícios, ficções. Sempre precários e sempre agudizando situações e contradições. Sempre com o reforço da sua arma 'natural' (na sua natureza...) de destruição de forças produtivas. Esse 'balão' e as suas 'bolhas' só deixarão de crescer demencialmente se houver força para os substituir pela valorização da economia real e pela capacidade de avançar para a alternativa, para o futuro, que, a nosso ver, é o socialismo. A não ser assim, corremos o risco de a destruição das forças produtivas ter efeitos catastróficos.

Tem enorme significado que o Decreto n 1 após a Revolução de Outubro (assinado por Lenine no dia 8 de Novembro de 1917) tenha sido o Decreto da Paz, que retirou a Rússia da $1^{a}$ Guerra Mundial, e que definiu o conceito de coexistência pacífica para as relações internacionais.

Desde sempre, e assim, a luta pelo socialismo tem estado intimamente ligada à luta pela Paz. Exatamente ao contrário do que se passa com a luta pela sobrevivência das relações sociais capitalistas, que assenta na destruição das forças produtivas e que recorre à guerra, pondo em risco a própria sobrevivência da Humanidade.

O contributo de Marx para o marxismo é, também, o de nos trazer, por diversas vias, à conclusão de que a História que vivemos (e que cada um vai 'escrevendo' com os seus contributos, valham eles o que valerem) é a luta de classes, e de que a luta contra a exploração de seres humanos por seres humanos é também uma luta pela Paz e pela sobrevivência da Humanidade. 
Resumo: Considerando o marxismo uma interpretação de fluir da História e um guia de ação para intervenção na permanente transformação da realidade, o A. procura trazer à reflexão a comprovação de que o marxismo não é obra acabada em Marx e que há marxismo para além de Marx. Para tanto, baseia-se no próprio Marx quando, no Livro Segundo de O Capital (tal como Engels o organizou), ao fazer a análise do processo de circulação de capital (enquanto expressão material), apenas considerava o dinheiro com base metálica por entender que, naquela fase do capitalismo, o dinheiro fictício e o dinheiro creditício não tinham relevância. $O$ que não é o caso de hoje, na atual fase do capitalismo. No entanto, apesar de Marx excluir o capital na forma dinheiro não metálico no Livro Segundo, ele não deixa de o considerar no Livro Terceiro, como o A. o pretende mostrar. A esta luz, o contributo de Marx para o marxismo e, através deste, para a compreensão do processo histórico e para a intervenção no sentido de transformar o mundo, foi importante no tempo e nas condições em que ele o estudou, e continua, hoje, a ser imprescindível.

Palavras-chave: marxismo, trabalho, valor, processo de circulação, capital-dinheiro, capital fictício, capital creditício, composição orgânica do capital, baixa tendencial da taxa de lucro, "factores" contrários à tendência.

Marx's contribution for Marxism

Abstract: Taking as a starting point Marxism as an interpretation of the flow of History and as an action guide for intervention in the permanent transformation of the reality, the author tries to bring to reflection the evidence that Marxism is not a finished opus and that there is Marxism beyond Marx. The author's idea is based on Marx himself: when he analyses the process of capital (as material expression) circulation in Book II of The Capital (such as Engels organized it), he only considered the money with metallic basis, as fiction money and credit money had no relevancy or significance on that phase of capitalism. This is not the case in the present phase of capitalism. However, although Marx excludes the capital in the form of money without metallic basis in Book II, he takes it in consideration in Book III as the author wants to show. This 'lecture' of Marx authorizes the author to conclude that Marx's contribution to Marxism and, through it, to the understanding of the historical process and to the inter- 
vention in order to world's transformation, was important in the epoch and conditions he studied it, and remains essential today.

Keywords: Marxism, Labour, Value, Circulation process, Capitalmoney, Fictional capital, Credit capital, Organic composition of capital, Tendency of the rate of profit to fall (TRPF), Situations against tendency.

Sérgio Ribeiro

Instituto Superior de Economia e Gestão

Universidade Técnica de Lisboa 